\title{
Climate change impact uncertainty assessment and adaptations for sustainable maize production using multi-crop and climate models
}

\author{
Mubashra Yasin ${ }^{1}$ - Ashfaq Ahmad ${ }^{2}$ - Tasneem Khaliq ${ }^{3} \cdot$ Muhammad Habib-ur-Rahman $^{4,5}$. Salma Niaz ${ }^{1}$. \\ Thomas Gaiser ${ }^{4}$. Iqra Ghafoor ${ }^{5} \cdot$ Hafiz Suboor ul Hassan $^{6} \cdot$ Muhammad Qasim $^{7}$. Gerrit Hoogenboom ${ }^{8}$
}

Received: 13 June 2021 / Accepted: 11 October 2021 / Published online: 27 October 2021

(c) The Author(s) 2021

\begin{abstract}
Future climate scenarios are predicting considerable threats to sustainable maize production in arid and semi-arid regions. These adverse impacts can be minimized by adopting modern agricultural tools to assess and develop successful adaptation practices. A multi-model approach (climate and crop) was used to assess the impacts and uncertainties of climate change on maize crop. An extensive field study was conducted to explore the temporal thermal variations on maize hybrids grown at farmer's fields for ten sowing dates during two consecutive growing years. Data about phenology, morphology, biomass development, and yield were recorded by adopting standard procedures and protocols. The CSM-CERES, APSIM, and CSM-IXIM-Maize models were calibrated and evaluated. Five GCMs among 29 were selected based on classification into different groups and uncertainty to predict climatic changes in the future. The results predicted that there would be a rise in temperature $\left(1.57-3.29^{\circ} \mathrm{C}\right)$ during the maize growing season in five General Circulation Models (GCMs) by using RCP 8.5 scenarios for the mid-century (2040-2069) as compared with the baseline (1980-2015). The CERES-Maize and APSIMMaize model showed lower root mean square error values (2.78 and 5.41), higher $d$-index (0.85 and 0.87) along reliable $R^{2}$ (0.89 and 0.89), respectively for days to anthesis and maturity, while the CSM-IXIM-Maize model performed well for growth parameters (leaf area index, total dry matter) and yield with reasonably good statistical indices. The CSM-IXIMMaize model performed well for all hybrids during both years whereas climate models, NorESM1-M and IPSL-CM5A-MR, showed less uncertain results for climate change impacts. Maize models along GCMs predicted a reduction in yield (8-55\%) than baseline. Maize crop may face a high yield decline that could be overcome by modifying the sowing dates and fertilizer (fertigation) and heat and drought-tolerant hybrids.
\end{abstract}

Keywords Sowing time · Maize hybrids · CERES-Maize, CSM-IXIM, APSIM-Maize, Phenology · LAI · TDM · Yield · Climate variability $\cdot$ Adaptation $\cdot$ Sustainable maize production

Responsible Editor:Philippe Garrigues

Mubashra Yasin

mhabibur@uni-bonn.de

$\triangle$ Muhammad Habib-ur-Rahman

mhabibur@uni-bonn.de; habib.rahman@mnsuam.edu.pk

1 Sugarcane Research Institute, Ayub Agricultural Research Institute, Faisalabad, Pakistan

2 Asian Disaster Preparedness Centre (ADPC), Islamabad, Pakistan

3 Agro-Climatology Lab, Department of Agronomy, University of Agriculture, Faisalabad, Pakistan
4 Institute of Crop Science and Resource Conservation (INRES), University Bonn, 53115 Bonn, Germany

5 Department of Agronomy, MNS-University of Agriculture Multan, Multan 60650, Pakistan

6 Sera Processing Lab, National Institute of Health, Islamabad, Pakistan

7 Department of Economics, Finance and Statistics, Jönköping University, Jönköping, Sweden

8 Institute for Sustainable Food Systems, University of Florida, 184 Rogers Hall, Gainesville, FL 32611, USA 


\section{Introduction}

Current production systems in the world are most vulnerable to climate change (IPCC 2014; Rosenzweig et al. 2014; Rahman et al. 2018; Wiebe et al. 2019; Shafqat et al, 2019). Changing climate is expected to decrease crop production and ultimately constitutes a threat to food security especially in arid to semi-arid climatic regions (Zhang et al. 2007; Ahmad et al. 2015; Ahmed et al. 2018a). Temperature increase and uncertain rainfall patterns have adverse impacts on crops' developmental phases, growth, and yield, and these impacts are already more pronounced in arid regions (Abbas et al. 2017; Ahmad et al. 2019; Ullah et al. 2019; Chattha et al. 2021). Variation in the climatic projections is most important in climate change studies for adoptions in crop production systems. Climatic changes include long-term variations in temperature, fluctuations in rainfall distributions, rising levels of $\mathrm{CO}_{2}$ and other atmospheric gases, and a rise in the existence of acute weather events (IPCC 2014, 2021; Porter 2005; Shafqat et al. 2021).

Maize is an important crop for food security, especially in developing countries. Demand is increased due to its numerous usages of domestic, commercial, and industrial as bio-fuel (Khaliq et al. 2008; Rosegrant et al. 2012; Asseng et al. 2014). However, maize production is adversely susceptible to extreme weather events due to climatic variability (Ahmed et al. 2018b). Changes in temperature especially elevated conditions have the potential to offset the optimum growth and development and shorten the growing seasons and ultimately reduced the yield (Yasin et al. 2019). Physiological and metabolic processes occurring in maize require optimum climatic conditions for proper growth and development (Wahid et al. 2007; Hatfield and Prueger 2015). Variation in optimum temperature ranges leads to a reduction in maize production; especially, these hazardous effects speed up under high day and night temperatures (Soler et al. 2007; Taylor et al. 2012; Yasin et al. 2019). The majority of the maize genotypes grown in these regions are extremely prone to raise temperature and drought stress. Crop genotypes with the ability to use water more efficiently can be used to cope with the water shortage conditions (Mubeen et al. 2020). As reproductive phases (flowering and grain-filling) are more vulnerable to high temperature, determination of optimum sowing time is essential for intensification and diversification in the current cropping system for sustainability (Mubeen et al. 2016; Ahmed et al. 2018a, b). Future projections show that there might be a rise of temperature up to $2.8{ }^{\circ} \mathrm{C}$ by 2069 in Pakistan (Ahmad et al. 2015). Among cereals crops getting successful maize production is under threat due to heat stress and less availability of other crucial resources like water and nutrients due to rising temperature (Lobell et al. 2011; Babel et al. 2019). Elevated $\mathrm{CO}_{2}$ has some positive effects on growth and yield, but maize being a $\mathrm{C} 4$ crop might have less advantage in photosynthetic accumulation for final biomass production (Ghannoum et al. 2000; Mina et al. 2019). Furthermore, it has also been reported in studies regarding future climate scenarios that interactive effects of $\mathrm{CO}_{2}$, projected temperature rise, and variability in rainfall could potentially reduce the positive effect of increasing $\mathrm{CO}_{2}$ concentration (Lobell et al. 2011; Hatfield and Prueger 2015). The predictions of unexpected periodic spells of heat stress are projected to occur more frequently in the region. These variations in climatic conditions are potentially altering the phases of maize phenology, growth, development, and yield and are a serious threat to sustainable maize production in the region and ultimately a threat to food security.

Crop growth models are innovative tools to determine the impacts of crop management practices like sowing dates, and plant genetics, and even interaction of these with the environment (Jones et al. 2003; Saddique et al. 2020a, b, c). Previously, these tools were used to assess climate change effects on crop production like effects of high temperature, elevated carbon dioxide, and uneven rainfall patterns (Lobell et al. 2011; Asseng et al. 2014). Various modeling techniques help determine the information about short-term and long-term management practices and production technologies for better crop production (Aurbacher et al. 2013). The Decision Support System for Agro-technology Transfer (DSSAT) is a complete package of system analysis approach having evaluation techniques of crop management including planting dates, irrigation, nutrients, and many others (Jones et al. 2003; Hoogenboom 2000; Hoogenboom et al. 2019). It has the potential to simulate the impacts and interactions of soil, plant genetics, and atmospheric variables on crop development, growth, and yield in various regions (Jones et al. 2003; Soler et al. 2007; Rahman et al. 2019; Saddique et al. 2019). The CSM-CERES-Maize under DSSAT model has been evaluated for maize crop management like irrigation, water, and nitrogen (Mubeen et al. 2016; Ahmed et al. 2018a, b; Ahmad et al. 2019). Furthermore, these are also being used to assess the impact of climate change on maize production under different climate change scenarios (Lobell et al. 2011; Mangani et al. 2019). Further, structural development under CERES-Maize was made related to leaf area, grain number, cob growth, integration and partitioning, and yield for better simulation and ultimately resulted in CSMIXIM-Maize model under the DSSAT (Lizaso et al. 2011). Better predictions regarding crop phenology are of prime importance to evaluate the changing climate effects on crop yield, as uncertainties in the simulations of crop yield could be additional (Ceglar et al. 2011). The APSIM (Agricultural 
production systems simulator) is a model with the potential to simulate the effect of thermo-temporal variations on crop growth, development, and physiology and provides alternative management practices for sustainable crop production (Keating et al. 2003; Holzworth et al. 2014).

Although a single model has been applied in different maize crop management, studies focusing on a broad range of sowing dates to assess temporal variation with genotypes applying multi-crop models currently are limited. Sound model calibration is the prerequisite for testing suitable management adaptation strategies for the development of sustainable productivity (Jones et al. 2003; Rahman et al. 2019). Model parameterization under local environmental conditions is a key for reliable assessment of climate change impacts and its application for decision support (He et al. 2010). Multi-model ensembles are being preferred to reduce the uncertainty due to model structure and complexities in processes (Asseng and Ewert 2013; Ewert et al. 2015; Uusitalo et al. 2015). Similarly, uncertainty in climate impact is also connected to climate models due to the complexities in atmosphere modeling, downscaling methods, and inadequate understanding of the processes (Wilby et al. 2004; Challinor et al. 2013; Osborne et al. 2013; Rahman et al. 2018). Dynamic process-based crop models have the potential to simulate the climate change impact (Ewert et al. 2015), but model calibration should be robust to minimize the risk of error and uncertainty (Bassu et al. 2014; Uusitalo et al. 2015; Rahman et al. 2019). Multiclimate and crop models provide more accurate and reliable results than the single modeling approach (Ruane et al. 2013; Martre et al. 2015; Rahman et al. 2018). This study aims to determine climate change impact uncertainty assessment on maize production using crop and climate model combinations for a mid-century under arid to semi-arid environmental conditions. Specifically, the objectives of the study are to (1) calibrate and evaluate the CERES-Maize, CSM-IXIMMaize, and APSIM maize crop models for simulation of crop behavior to a broad range of sowing dates with different hybrids, (2) explore the potential impact of climate change on maize productivity based on a combination of the output of five climate models with the crop models, and (3) evaluation of uncertainty in the model outputs and development of adaptations for sustainable maize production in changing climatic scenarios.

\section{Materials and methods}

\section{Experimental details and environmental conditions of the study site}

The field experiments were conducted in semi-arid region $\left(31^{\circ} 30 \mathrm{~N}, 73^{\circ} 26 \mathrm{E}\right)$. Mixed cropping is dominant in this region, but still, maize crop has a significant contribution in terms of the area due to industrial demand and farmer's preference to grow maize for grain production and economic returns. The study experiences prominent changes in air temperature of day and night and even significant fluctuations during maize growing seasons. Rainfall during this season is also highly variable. Historic time series of climate observations include daily minimum ( $T \min )$, maximum ( $T \max )$, and precipitation, solar radiation, humidity, and wind speed were recorded by the Pakistan Meteorology Department (PMD). Detailed weather conditions during both maize growing years 2014 and 2015 can be found in the paper by Yasin et al. (2019). The soil is medium-textured with alkaline properties. The $\mathrm{pH}$ increases with depth. The topsoil nitrogen content is $0.06 \%$, which decreased in the subsoil. Soil is classified as brown silty loam, and it is well-drained and calcareous. It has a very low organic carbon (OC) concentration. Detailed methodology and results are presented in a paper published by the author (Yasin et al. 2019). Soil hydrological properties such as field capacity (drained upper limit $=$ DUL), permanent wilting point (lower limit $=$ LL), saturated hydraulic conductivity (SSKS), and saturated soil water content (SSAT) were presented in Table 1. The four well-adopted maize hybrids (DK-6103, NK-8711, P-30-15-43, and YH-1898) in this region were sown at

Table 1 Soil physical, chemical composition, and hydrological properties used for model simulations

\begin{tabular}{|c|c|c|c|c|c|c|c|c|c|c|c|}
\hline Depth $(\mathrm{cm})$ & SLCL (\%) & SLOC $(\%)$ & SLSI $(\%)$ & SLHW & $\begin{array}{l}\mathrm{LL} \\
\left(\mathrm{cm} \mathrm{cm}^{-1}\right)\end{array}$ & $\begin{array}{l}\text { DUL } \\
\left(\mathrm{cm} \mathrm{cm}^{-1}\right)\end{array}$ & $\begin{array}{l}\text { SSAT } \\
\left(\mathrm{cm} \mathrm{cm}^{-1}\right)\end{array}$ & $\begin{array}{l}\text { SBDM } \\
\left(\mathrm{g} \mathrm{cm}^{-3}\right)\end{array}$ & SLNI (\%) & $\begin{array}{l}\text { SSKS } \\
\left(\mathrm{cm} \mathrm{h}^{-1}\right)\end{array}$ & SRGF \\
\hline $0-15$ & 10 & 0.53 & 56 & 8.3 & 0.090 & 0.253 & 0.505 & 1.23 & 0.04 & 0.68 & 1 \\
\hline $15-30$ & 13 & 0.20 & 53 & 8.4 & 0.096 & 0.247 & 0.483 & 1.30 & 0.02 & 0.68 & 1 \\
\hline $30-45$ & 17 & 0.13 & 53 & 8.2 & 0.115 & 0.266 & 0.479 & 1.31 & 0.02 & 0.67 & 0.49 \\
\hline $45-60$ & 17 & 0.13 & 53 & 8.2 & 0.115 & 0.266 & 0.479 & 1.31 & 0.02 & 0.67 & 0.33 \\
\hline $60-90$ & 16 & 0.12 & 54 & 8.3 & 0.109 & 0.261 & 0.483 & 1.30 & 0.01 & 0.66 & 0.21 \\
\hline $90-125$ & 8 & 0.12 & 58 & 8.4 & 0.069 & 0.225 & 0.505 & 1.24 & 0.01 & 0.68 & 0.09 \\
\hline
\end{tabular}

$S L C L$ clay contents in soil, $S L O C$ soil organic carbon, $S L S I$ silt contents in soil, $S L H W$ Soil pH in water, $L L$ lower limit, DUL drained upper limit, SSAT saturation, SBDM soil bulk density, SLNI soil total nitrogen concentration, SSKS saturated hydraulic conductivity, SRGF soil root growth factor 
various sowing dates having 15 days' intervals starting from 15 January and ending on 1 June. Fifteen plants from each experimental unit were tagged randomly to monitor the data of crop developmental phases. Crop growth and physiology were observed at regular intervals and yield, and yield attributes were recorded at final harvest by following standard procedures and protocols. The experimental site experiences enormous variations in maximum and minimum temperature during the crop season. In 2014, maximum and minimum temperature was $41.8{ }^{\circ} \mathrm{C}$ and $4.5{ }^{\circ} \mathrm{C}$, while in 2015 maximum and minimum temperature was $38.7^{\circ} \mathrm{C}$ and $6.9^{\circ} \mathrm{C}$ respectively. The temperature was a bit low in the early months of the sowing period, increased up to maximum in June, and then started declining to the end of the year. Rainfall variability occurs during 2015 as there were plenty of rainfalls with high intensity as compared to 2014 . The monthly average values of minimum (Tmin), maximum (Tmax) temperatures, precipitation, and solar radiations for the period of study were presented in Fig. 1.

\section{Data generation of climate change scenarios and selection of GCMs}

Historic daily weather data of 35 years including all-weather variables (solar radiation, maximum and minimum temperature, precipitation, surface wind, dew point temperature, relative humidity, and vapor pressure) were named as baseline data (1980-2015). This baseline data set was tested for quality by following the standard protocols, and then the data set was used for future climate scenario generation using the output of 29 GCMs from the Coupled Model Inter-comparison Project (CMIP5) (Ruane et al. 2015). Depending on how baseline climatic data with daily changes in weather variables was executed, the further detailed methodology can be found in Rahman et al. (2018) and Ahmad et al. (2018). Further, mean and variability change scenarios were also deployed using stretched distribution approach that is related to quantile mapping (Ruane et al. 2015) for all GCMs for calibration. Then, climate change scenarios for the study region were developed for all GCMs for the period of midcentury (2040-2069) under the representative concentration pathway 8.5 (AgMIP 2013a; 2014; Ahmad et al. 2015). Further details about the methodology can be found in Rahman et al. (2018). Five less uncertain GCMs for temperature and precipitation during the maize growing season were selected out of $29 \mathrm{GCMs}$, based on maximum consensus. The percentage precipitation change vs. mean temperature change in the scenarios were used as criteria to find out the less uncertain group of GCMs for this region (Ruane et al. 2017). Further, these GCMs were classified into the following groups: HotWet (IPSL-CM5A-MR), HotDry (CMCC-CMS), Middle (NorESM1-M), CoolWet (CESM1-BGC), and CoolDry (INMCM4). The Several GCMs depend on deviation (ensemble standard) in the temperature and rainfall variations during maize growing season. $\mathrm{CO}_{2}$ concentrations of $380 \mathrm{ppm}$ and $571 \mathrm{ppm}$ were used in this study for baseline (Rosenzweig et al. 2013) and mid-century conditions (Taylor et al. 2012), respectively under RCP 8.5.

\section{Description of crop models}

The CSM-CERES-Maize, CSM-IXIM, and APSIMMaize models were tested in this study. These three models were selected based on their various in-built characters mentioned below and to evaluate their performance in local climatic conditions. The CSM-CERESMaize and CSM-IXIM models under the DSSAT version 4.7.5.0 were used in this study (Hoogenboom et al.

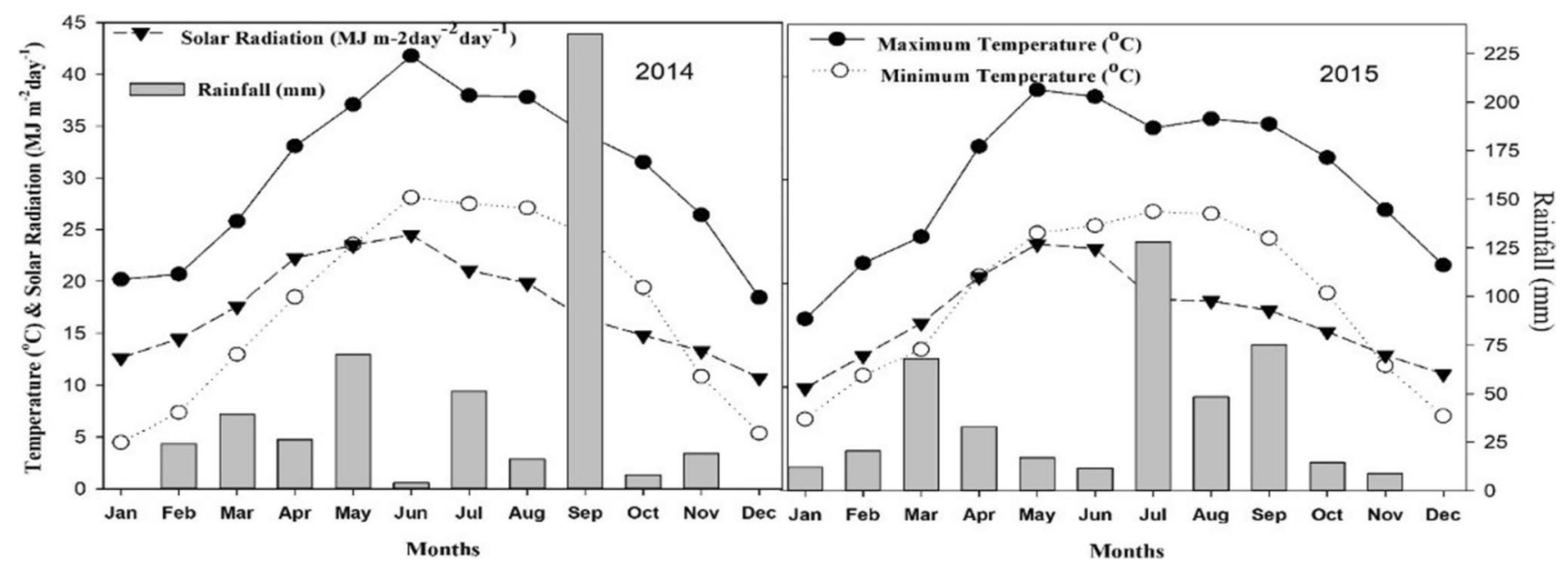

Fig. 1 Climatic data for the spring maize growing experimental years (2014 and 2015), monthly minimum $\left({ }^{\circ} \mathrm{C}\right)$, maximum $\left({ }^{\circ} \mathrm{C}\right)$ temperature $\left({ }^{\circ} \mathrm{C}\right)$, monthly rainfall $(\mathrm{mm})$, and cumulative monthly solar radiations $\left(\mathrm{M} \mathrm{J} \mathrm{m}^{-2}\right)$ 
2019). These models simulate the phenology, growth, and yield of maize while having an interactive effect on plant genetics, soil characteristics, crop management, and environmental conditions (Jones et al. 2003; Lizaso et al. 2013). The temperature has strong effects on growth and development phases, whereas $\mathrm{CO}_{2}$ affects both daily photosynthesis and transpiration; a detailed description of the original CERES-Maize model is presented in Ritchie and Alagarswamy (2003). The CSM-IXIM is a newly developed maize simulation model with more mechanistic features. It was modified with a more number of improvements and new modules from the CSM-CERES that contain leaf area expansion and senescence. The CSM-IXIM has better potential to simulate the LAI, cob growth, grain number, grain yield, carbon assimilation, partitioning, and nitrogen accretion and distribution. Two more genetic coefficients for the simulation of per-leaf foliar surface estimated LAI more accurately considered in the CSM-IXIM than CSM-CERES. These are simulated using sigmoidal functions to elucidate the expansion, longevity, and senescence of individual leaves (Lizaso et al. 2011, 2018; Yakoub et al. 2017). The combination of approaches in these two models CM-KEN and CM-SAT was used to develop the APSIM-Maize model (Keating et al. 2003), and it is being used for various maize cultivars around the world, under different management and climatic conditions (Bassu et al. 2014). The APSIM comprises the basic applications, cropping systems, crop management, intercropping and species interactions with water balance, soil impacts, land use studies, and crop adaptation (Keating et al. 2003). The APSIM-Maize model version 7.9 was used in this study, and further basic information about principles can be found in Keating et al. (2003) and Holzworth et al. (2014). The APSIM model can simulate soil water, C, $\mathrm{N}$, and $\mathrm{P}$ dynamics and their interactions within the crop and its management systems by utilizing daily weather data (solar radiation, maximum and minimum temperatures, precipitation). Daily potential above-ground biomass production of various crops can be calculated using stage-related radiation-use efficiency (RUE) constrained by climate, soil water and nitrogen concentration, and available leaf area (Keating et al. 2003).

\section{Crop model calibration and evaluation with field data}

The process of calibration reduces the difference between observed and corresponding simulated data mostly by modifying and adjusting the cultivar parameters of the models. Hybrids were calibrated and evaluated by using comprehensive field measurements about phenology, morphology physiology, growth, yield, and yield components collected in the maize growing seasons of 2014 and 2015. The sowing date (30 January 2014 for spring) faced minimum weather stress and produced maximum yield as compared with the rest of all sowing dates and was therefore used for calibration of the models for all hybrids. Details about crop management and data are presented in Yasin et al. (2019).

The genetic coefficients for the studied maize hybrids under DSSAT model for both the CSM-CERES-Maize and CSM-IXIM maize models were estimated by following the protocols of the generalized likelihood uncertainty estimation (GLUE) and sensitivity analysis tool associated with DSSAT (He et al. 2009; Rahman et al. 2019). The GLUE package optimizes the goodness of fit between observation and simulated parameter values (crop phenology, crop yield, and biomass, etc.). the GLUE package is built in the DSSAT. Before running the GLUE, the user needs to select some information such as crop type, a cultivar (from a cultivar list that is available in the DSSAT database for different crops), and the experimental treatments regarding cultivars grown in the field experiment. The GLUE runs 10,000 times to obtain the best cultivar coefficients. If these coefficients do not lead to an adequate fit between simulated and observed values, then a trial-and-error method (Mavromatis et al. 2001) was used to get a close match of observed with simulated values by varying thermal time and photothermal time requirements for different phenological phases of the hybrids. Simulations were stopped when they fulfilled the statistical requirement between observed and simulated data (Hunt and Boote 1998). Cultivar coefficients were determined successively starting from P1, P2, P5, and PHINT followed by G2 and G3 in the case of CSM-CERES-Maize and CSM-IXIM-Maize models.

The APSIM-Maize model was supplied with local input parameters which were directly recorded during field experimentation such as weather parameters, soil physical and chemical characteristics, crop management practices. Some other parameters which cannot be measured directly or whose values possess greater uncertainty (such as coefficients of crop hybrids) needed to be re-adjusted or calibrated. In this case, the model calibration was done with the data set of the field experiment in 2014 and the sowing date (30th January 2014) where the crop showed the best performance under maximum input conditions. Simulated outputs for crop growth, development, and production were then compared with observed values from the experiment. Parameters were readjusted within reasonable limits when inconsistencies between observed and simulated values were found, and the process was repeated until adequate behavior of the model was attained (Gaydon et al. 2017). Cultivar coefficients were determined successively such as $<$ tt_emerg_to_endjuv $>$, $<$ tt_flower_to_maturity $>,<$ tt_flag to_flower $>,<$ tt_flower_to_start_grain, $<$ head_grain_no_ max_ub $>,<$ x_stem_wt $>$ in case of APSIM-Maize model. 


\section{Model statistics}

In this study, the model was evaluated using the coefficient of determination $\left(R^{2}\right), d$-index value (Willmott et al. 1985), mean percentage difference (MPD), and root mean square error (RMSE) (Wallach and Goffinet 1989) between simulated and observed data, while models were compared with the formula equation of model efficiency (EF). The $d$-index value was calculated using the following equation:

$d=1-\left[\frac{\sum_{i=1}^{n}\left(P_{i}-O_{i}\right)^{2}}{\sum_{i=1}^{n}\left(\left|P_{i}^{\prime}\right|+\left|O_{i}^{\prime}\right|\right)^{2}}\right], 0 \leq d \leq 1$

where, $n=$ number of observations, $P_{i}=$ predicted value for the $i$ th measurement, $O_{i}=$ observed value for the $i$ th measurement, $\bar{O}=$ the overall mean of observed values, $P_{i}^{\prime}=P_{i}-\bar{O}$ and $O_{i}^{\prime}=O_{i}-\bar{O}$. The RMSE is the root mean square error, which was calculated using the following equation:

$R M S E=\sqrt{\frac{\sum_{i=1}^{n}\left(P_{i}-O_{i}\right)^{2}}{n}}$

where $n$ denotes the number of the observations used for comparisons, $P_{i}$ are the simulated values while $O_{i}$ are the observed ones used in the above equation. RMSE was used to determine the statistical differences between observed and simulated variables; it could be computed by using Eq. 2 to determine the predictability degree (Soler et al. 2007). Higher $d$-index value and lower RMSE value indicated a good fit between the simulated and observed data. $R^{2}$ (coefficient of determination) and $d$-index values range from 0 to 1 , and perfect agreement between observed and simulated data is represented by closer to 1 .

Mean percent deviation indicates the deviation of simulated from observed values, a negative change revealed the underprediction while a positive change indicates the overprediction of model values.

$E F=1-\left[\frac{\sum_{i}\left(\boldsymbol{O}_{i}-\boldsymbol{P}_{i}\right)^{2}}{\sum_{i}\left(\boldsymbol{O}_{i}-\overline{\boldsymbol{O}}\right)^{2}}\right]$

The efficiency of a model (EF) showed the accuracy and model performance, and it can be computed by using Eq. 3, where $O_{i}$ is the ith observation recorded, $P^{\prime}{ }_{i}$ is the ith model simulation and $\bar{O}$ is the average overall observations.

\section{Climate change impact assessment and adaptation management development for sustainable maize production}

Historical daily weather observations comprising 35 years (1980-2015) temperature, solar radiation, rainfall, and atmospheric $\mathrm{CO}_{2}(360 \mathrm{ppm})$ were used as baseline climate data. The quality of observed weather data was checked, and data sets were converted adopting the AgMIP format (Rosenzweig et al. 2013; Ahmad et al. 2015). Climate change projections were generated using the output of the five selected GCMs from the latest CMIP5 family (Taylor et al. 2012) under RCP 8.5 scenarios $\left(\mathrm{CO}_{2}\right.$ concentration at $571 \mathrm{ppm})$. Calibration treatment with all its management (sowing, fertilizer, and irrigation) is used for the climate change impact assessment. The five GCMs were selected to represent the uncertainty in projected temperature and rainfall changes based on five possible climate characteristics (cool/wet, cool/dry, hot/wet, hot/dry, middle). These monthly changes were then imposed on the baseline climate series for the two seasons used in the analyses using a distribution approach (Ruane et al. 2014). Crop management options like sowing time, planting density, nitrogen application, irrigation strategies, soil fertility potential, and crop genetic potential (duration, thermal time, and genetic makeup for yield) were tested in the models to find the best management practices for sustainable maize production in the future (Rahman et al. 2018). Maize crop models were calibrated with sowing date (30 January 2014) and then validated with other nine sowing dates. The calibrated models were run across seasons for the proposed adaptations in case of sowing dates, i.e., 15-day interval treatments of sowing dates were checked for early and late sowing dates for all five GCMs during mid-century RCP 8.5. Similarly, for N application and irrigation management were tested to assess the potential of hybrids under future climate to develop the adaption for sustainable maize production.

\section{Results}

\section{Historic weather data and future climate trends}

Daily weather data of the previous 35 years (1980-2015) temperature, solar radiations, rainfall, and atmospheric $\mathrm{CO}_{2}$ were used as baseline climatic data. A warming trend is accelerating with short winter spells and delayed monsoon season. The increase in average daily maximum temperature of up to $0.47{ }^{\circ} \mathrm{C}$ has been observed, and the incidence of heatwaves has been recorded. Average annual rainfall has been decreased by $10-15 \%$, whereas distribution and 
occurrence of drought spells are uneven. Results from the climate scenarios revealed that both minimum and maximum temperature will increase, and higher variability in precipitations in the maize growing season is expected in all five GCMs with RCP 8.5 scenarios during the mid-century (2040-2060). All the five GCMs predicted an increase with a range of $2.79-4.28^{\circ} \mathrm{C}$ in temperature on an average during mid-century, while for rainfall there might be a change of 6-248 (mm) during the mid-century period.

\section{Calibration of maize models}

Introducing or adding any new cultivars/hybrids into the crop models, many of the genetic parameters had to be adjusted according to their local condition, and this process is known as calibration. Four maize hybrids (DK-6103, NK-8711, P-1543, and FH-1898) were calibrated separately with the sowing date (30 January) for the year 2014. Six crop parameters (days to anthesis, days to maturity, maximum leaf area index, total dry matter, grain yield, and harvest index) observed during field experimentation were used in the calibration process. The genetic coefficients of the three models were readjusted to match the simulated and observed values of days to anthesis and maturity, grain yield, biomass at harvest, harvest index, and maximum LAI. The CSM-CERES-Maize requires a set of six cultivar genetic coefficients for simulation of phenology, growth, and grain yield, whereas CSM-IXIM-Maize has eight and APSIM 14 cultivar-specific genetic coefficients (Table 2). The calibrated values of the genetic coefficients of the three models
Table 2 Genetic coefficients of spring maize hybrids adjusted in the CSM-CERES-Maize and IXIM-Maize models during calibration
Table 3 Genetic coefficients of spring maize hybrids adjusted in the APSIM-Maize model during calibration

\begin{tabular}{|c|c|c|c|c|c|}
\hline \multirow[t]{2}{*}{ Model } & \multirow[t]{2}{*}{ Cultivar coefficients } & \multicolumn{4}{|c|}{ Calibrated value } \\
\hline & & DK-6103 & NK-8711 & P-1543 & FH-1898 \\
\hline \multirow[t]{6}{*}{ CERES-Maize } & $\mathrm{P} 1\left({ }^{\circ} \mathrm{C} \mathrm{d}\right)$ & 282.0 & 276.0 & 276.0 & 285.0 \\
\hline & $\mathrm{P} 2$ (d) & 0.660 & 0.580 & 0.580 & 0.620 \\
\hline & $\mathrm{P} 5\left({ }^{\circ} \mathrm{C} \mathrm{d}\right)$ & 795.0 & 857.0 & 860.0 & 870.0 \\
\hline & $\mathrm{G} 2$ & 817.0 & 672.0 & 660.0 & 795.0 \\
\hline & $\mathrm{G} 5\left(\mathrm{mg} \mathrm{d}^{-1}\right)$ & 10.90 & 10.30 & 9.90 & 9.12 \\
\hline & PHINT $\left({ }^{\circ} \mathrm{C} \mathrm{d}\right)$ & 38.90 & 39.40 & 38.90 & 40.0 \\
\hline \multirow[t]{8}{*}{ IXIM-Maize } & $\mathrm{P} 1\left({ }^{\circ} \mathrm{C} \mathrm{d}\right)$ & 255.0 & 250.0 & 260.0 & 275.0 \\
\hline & $\mathrm{P} 2$ (d) & 0.930 & 0.810 & 0.900 & 0.760 \\
\hline & $\mathrm{P} 5\left({ }^{\circ} \mathrm{C} \mathrm{d}\right)$ & 800.0 & 770.0 & 700.0 & 855.0 \\
\hline & $\mathrm{G} 2$ & 750.0 & 751.0 & 772.0 & 690.0 \\
\hline & $\mathrm{G} 5\left(\mathrm{mg} \mathrm{d}^{-1}\right)$ & 7.90 & 8.40 & 7.95 & 7.80 \\
\hline & PHINT ( $\left.{ }^{\circ} \mathrm{C} \mathrm{d}\right)$ & 41.00 & 40.00 & 39.00 & 40.00 \\
\hline & $\mathrm{AX}\left(\mathrm{cm}^{2} / \mathrm{leaf}\right)$ & 760.0 & 780.0 & 760.0 & 750.0 \\
\hline & $\operatorname{ALL}\left({ }^{\circ} \mathrm{C} d\right)$ & 850.0 & 866.0 & 800.0 & 790.0 \\
\hline
\end{tabular}

\begin{tabular}{llllll}
\hline Model & Cultivar coefficients & \multicolumn{2}{l}{ Calibrated value } & & \\
\cline { 3 - 5 } & & DK-6103 & NK-8711 & P-1543 & FH-1898 \\
\hline APSIM-Maize & tt_emerg_to_endjuv & 160.5 & 160.5 & 171.2 & 165.4 \\
& tt_flower_to_maturity & 650 & 636 & 643 & 640 \\
& head_grain_no_max & 481.2 & 524.6 & 490.3 & 512.2 \\
& grain_gth_rate & 13.00 & 13.00 & 12.50 & 13.60 \\
& X_stem_wt units="g/stem" & 200 & 250 & 230 & 228 \\
& y_height units="mm" & 2900 & 2910 & 2775 & 2800 \\
& est_days_endjuv_to_init & 1 & 1 & 1 & 1 \\
& tt_endjuv_to_init & 1.8 & 1.7 & 1.5 & 1.8 \\
& photoperiod_crit1 & 10.6 & 11.5 & 10.8 & 10.6 \\
& photoperiod_crit2 & 24.0 & 25.0 & 22.0 & 24.0 \\
& photoperiod_slope & 7.9 & 7.5 & 7.7 & 7.7 \\
& tt_flag_to_flower & 34.0 & 35.0 & 36.4 & 35 \\
& tt_flower_to_start_grain & 114 & 115 & 114 & 116 \\
& tt_maturity_to_ripe & 0.1 & 0.0 & 0.1 & 0.1 \\
\hline
\end{tabular}


for four spring maize hybrids (DK-6103, NK-8711, P-1543, and FH-1898) are presented in Tables 2 and 3.

\section{Evaluation of model performance with respect to mean percentage difference}

\section{Model response to duration of major phenological events}

The results showed significant differences among all three crop models $(P<0.01)$ in terms of mean percent difference between observed and simulated values for days to anthesis and days to maturity (Table 4). The CSM-IXIM-Maize model showed a higher mean percent difference between observed and simulated for hybrid DK-6103 and NK-8711 when compared with the CERES-Maize and APSIM-Maize model as both exhibited lesser mean percent difference in case of days to anthesis and days to maturity. Root mean square error was higher for simulations of CSM-IXIMMaize model (Table 3). Mean percent difference between observed and simulated days to anthesis and days to maturity for hybrid P-1543 was found $(-1.47$ and -0.70$)$ respectively in the APSIM-Maize model, due to higher differences in a simulation of days to anthesis and maturity than observed values. The CERES-Maize model predicted high ( -3.57 and -2.56) mean percent difference in case of days to anthesis and days to maturity respectively. Mean percent difference between observed and simulated days to anthesis for hybrid FH-1898 was found non-significant for all three models, whereas the CSM-IXIM-Maize model gave more (0.193) mean percent difference in case of days to maturity. Root mean square error was recorded higher in simulations of the APSIM-Maize model (Table 4).

\section{Crop model response to maize growth (leaf area index and biomass)}

Significant differences were found among all three crop models $(P<0.01)$ in terms of the mean percent difference between observed and simulated values of leaf area index, total dry matter (Table 4). The APSIM-Maize model predicted greater values of the mean percent difference between observed and simulated values of maximum leaf area index for hybrid DK-6103, NK-8711, and FH-1898, while the other two models were statistically at par with each other for mean percent difference of leaf area index. The CERESMaize model gave a higher mean percent difference in case of total dry matter due to higher simulation of total dry matter than observed total dry matter. The APSIM-Maize model presented a high simulation of total dry matter then observed total dry matter with the mean percent difference of -2.45 .

Table 4 Comparison of mean percent difference (\%) of model simulations for phenological, growth, and yield parameters during calibration of spring hybrids (different letters denote significant differences between models at $P<0.05)(N=9)$

\begin{tabular}{|c|c|c|c|c|c|c|c|}
\hline \multirow[t]{2}{*}{ Hybrids } & \multirow{2}{*}{$\begin{array}{l}\text { Treatments } \\
\text { Crop models }\end{array}$} & \multicolumn{6}{|l|}{ MPD (\%) } \\
\hline & & Days to anthesis & Days to maturity & LAI & TDM $\left(\mathrm{kg} \mathrm{ha}^{-1}\right)$ & Yield $\left(\mathrm{kg} \mathrm{ha}^{-1}\right)$ & $\mathrm{HI}$ \\
\hline \multicolumn{8}{|l|}{ DK-6103 } \\
\hline & CERES-Maize & $2.72 \mathrm{~B}$ & $1.13 \mathrm{~B}$ & $12.28 \mathrm{~B}$ & $1.31 \mathrm{~A}$ & $3.28 \mathrm{~A}$ & $22.65 \mathrm{~A}$ \\
\hline & CSM-IXIM-Maize & $5.53 \mathrm{~A}$ & $3.45 \mathrm{~A}$ & $12.62 \mathrm{~B}$ & $-1.32 \mathrm{~B}$ & $2.27 \mathrm{C}$ & $13.53 \mathrm{~B}$ \\
\hline & APSIM-Maize & $1.21 \mathrm{C}$ & $0.76 \mathrm{C}$ & $20.29 \mathrm{~A}$ & $-2.45 \mathrm{C}$ & $2.44 \mathrm{~B}$ & $2.44 \mathrm{C}$ \\
\hline & HSD (0.05) & 0.06 & 0.03 & 3.08 & 0.043 & 0.029 & 0.03 \\
\hline & Significance & $* *$ & $* *$ & $* *$ & $* *$ & $* *$ & $* *$ \\
\hline \multirow[t]{5}{*}{ NK-8711 } & CERES-Maize & $-3.62 \mathrm{~B}$ & $-2.78 \mathrm{~B}$ & $6.6917 \mathrm{~B}$ & $-1.17 \mathrm{~A}$ & $3.37 \mathrm{~B}$ & $13.57 \mathrm{~A}$ \\
\hline & CSM-IXIM-Maize & $-4.48 \mathrm{C}$ & $-2.77 \mathrm{~B}$ & $1.4575 \mathrm{C}$ & $-4.54 \mathrm{~B}$ & $0.50 \mathrm{C}$ & $11.32 \mathrm{~B}$ \\
\hline & APSIM-Maize & $-0.32 \mathrm{~A}$ & $-0.19 \mathrm{~A}$ & $12.698 \mathrm{~A}$ & $-5.04 \mathrm{C}$ & $9.10 \mathrm{~A}$ & $9.10 \mathrm{C}$ \\
\hline & HSD (0.05) & 0.076 & 0.031 & 0.526 & 0.043 & 0.039 & 0.038 \\
\hline & Significance & $* *$ & $* *$ & $* *$ & $* *$ & $* *$ & $* *$ \\
\hline \multirow[t]{5}{*}{ P-1543 } & CERES-Maize & $-3.57 \mathrm{C}$ & $-2.56 \mathrm{C}$ & $17.88 \mathrm{~A}$ & $-0.28 \mathrm{~A}$ & $1.01 \mathrm{~B}$ & $18.29 \mathrm{~A}$ \\
\hline & CSM-IXIM-Maize & $-2.68 \mathrm{~B}$ & $-1.45 \mathrm{~B}$ & $14.71 \mathrm{~B}$ & $-1.36 \mathrm{C}$ & $1.34 \mathrm{~A}$ & $14.96 \mathrm{~B}$ \\
\hline & APSIM-Maize & $-1.47 \mathrm{~A}$ & $-0.70 \mathrm{~A}$ & $14.22 \mathrm{~B}$ & $-1.10 \mathrm{~B}$ & $-0.04 \mathrm{C}$ & $-4.04 \mathrm{C}$ \\
\hline & HSD (0.05) & 0.70 & 0.50 & 0.526 & 0.044 & 0.0384 & 0.0381 \\
\hline & Significance & $* *$ & $* *$ & $* *$ & $* *$ & $* *$ & $* *$ \\
\hline \multirow[t]{5}{*}{ FH-1898 } & CERES-Maize & 0.109 & $-0.37 \mathrm{~B}$ & $8.30 \mathrm{~B}$ & $-1.90 \mathrm{C}$ & $-0.84 \mathrm{C}$ & $6.07 \mathrm{~B}$ \\
\hline & CSM-IXIM-Maize & 0.106 & $0.193 \mathrm{~A}$ & $8.30 \mathrm{~B}$ & $-0.53 \mathrm{~B}$ & $-0.14 \mathrm{~A}$ & $11.8 \mathrm{~A}$ \\
\hline & APSIM-Maize & -0.20 & $-0.94 \mathrm{C}$ & $9.56 \mathrm{~A}$ & $-0.30 \mathrm{~A}$ & $-0.38 \mathrm{~B}$ & $-0.38 \mathrm{C}$ \\
\hline & HSD (0.05) & 0.399 & 0.419 & 0.525 & 0.043 & 0.039 & 0.037 \\
\hline & Significance & NS & $* *$ & $* *$ & $* *$ & $* *$ & $* *$ \\
\hline
\end{tabular}


The MPD between observed and simulated for hybrid P-1543 were recorded higher (17.68) in CERES-Maize model for maximum leaf area index. All models showed oversimulation trend for total dry matter. Root mean square error was greater in simulations of the CSM-IXIM-Maize model (Table 4).

\section{Model performance and response to yield and yield components of different hybrids}

The results revealed significant differences among all three crop models $(P<0.01)$ in terms of the mean percent difference between observed and simulated values for grain yield and harvest index (Table 4). The CERES-Maize model predicting a higher mean percent difference between observed and simulated for hybrid DK-6103 recorded more (3.28 and 22.65) for grain yield and harvest index respectively, whereas the CSM-IXIM-Maize showed less mean percent difference for grain yield, and the APSIM-Maize model gave less mean percent difference (2.44) in the case of harvest index. The mean percent difference between observed and simulated for hybrid P-1543 and FH-1898 was found higher in the CSM-IXIM-Maize model in the case of grain yield. The APSIM-Maize model over-stimulated the grain yield of hybrid NK-8711 and depicted a higher mean percent difference between observed and predicted values. Root mean square error was higher in simulations of the CERES-Maize model and CSM-IXIM-Maize model (Table 4).

\section{Evaluation of model performance for the coefficient of determination, RMSE, and d-index}

Maize multi-models were evaluated for behavior by analyzing the relationship between simulated and observed values of all output variables which were used in the process of calibration such as days to anthesis, days to maturity, leaf area index, total dry matter $\left(\mathrm{kg} \mathrm{ha}^{-1}\right)$, grain yield $(\mathrm{kg}$ $\mathrm{ha}^{-1}$ ), and harvest index. All three models (CERES-Maize, CSM-IXIM-Maize, and APSIM-Maize) presented a good and smooth relationship between observed and simulated values. CERES-Maize and APSIM-Maize models showed lower RMSE values (2.78 and 5.41), higher $d$-index ( 0.85 and 0.87$)$ along with reliable $R^{2}(0.89)$ for days to anthesis and days to maturity respectively as compared to CSMIXIM-Maize, which showed a bit higher RMSE (10.50) with reliable $R^{2}$ value (0.85) for all sowing dates and hybrids during the spring season (Fig. 2).

The CSM-IXIM-Maize model performed well for leaf area index and total dry matter, with the lowest RMSE (0.79 and 1326), good $d$-index (0.86 and 0.85$)$ respectively, and fair $R^{2}$ value (0.86) when compared with the other two models (Fig. 3). The CSM-IXIM-Maize model performed very well for grain yield with the lowest RMSE (716.3), high d-index (0.88), and fair $R^{2}$ value $(0.87)$ when compared with the other two models, whereas for harvest index CERES-Maize predictions were better with lower RMSE (4.86), higher $d$-index (0.87), and reliable $R^{2}$ value (0.85) (Fig. 4). Overall, $d$-index values were recorded higher ( 0.80 to 0.88$)$ for all hybrids at all sowing dates.

\section{Performance of maize multi-models during the evaluation}

Model evaluation was done for days to anthesis, days to maturity, leaf area index, total dry matter, grain yield, and harvest index to check the maize multi-model performance. Exceeding probability (Figures 5, 6, and 7) associated with the days to anthesis, days to maturity, leaf area index, total dry matter, grain yield, and harvest index during the spring season for both years (2014 and 2015). The CERES-Maize and APSIM-Maize model performance were very good for days to anthesis and days to maturity. Simulations of the CERES-Maize model were very well for days to anthesis during both years with less RMSE value 2.78 and 3.51 respectively as compared to CSMIXIM-Maize and APSIM-Maize models (Fig. 5). A similar trend was observed for days to maturity. For leaf area index, the simulations of CSM-IXIM-Maize model were very good during both years with lower RMSE value 0.79 and 0.70 respectively as compared to other two models, whereas APSIM-Maize simulated total dry matter very well during both years with RMSE value (1326 and 1968) respectively while comparing with other models (Fig. 6). The CSM-IXIM-Maize model simulations for grain yield were good during both years with lower RMSE (716 and 790), respectively (Fig. 7), whereas the APSIM-Maize simulation for grain yield was also very good during both years with RMSE value (856 and 911.8). The harvest index was simulated very well by CSM-IXIM-Maize model during both years with lower RMSE (2.77 and 3.10), respectively (Fig. 7). The performance efficiency of all three models for crop growth, development, and yield parameters was determined during both years. Significant differences $(P<0.05)$ were found among all maize models during the year 2014, whereas non-significant differences were found during 2015 (Fig. 8). The performance efficiency of APSIM-Maize and CSM-IXIM-Maize models was higher than CERES-Maize model during 2014, and these two models are statistically at par with the means of each other. On average, the simulating behavior of the CSM-IXIM-Maize model was very well under semi-arid conditions during both years (Fig. 8). 


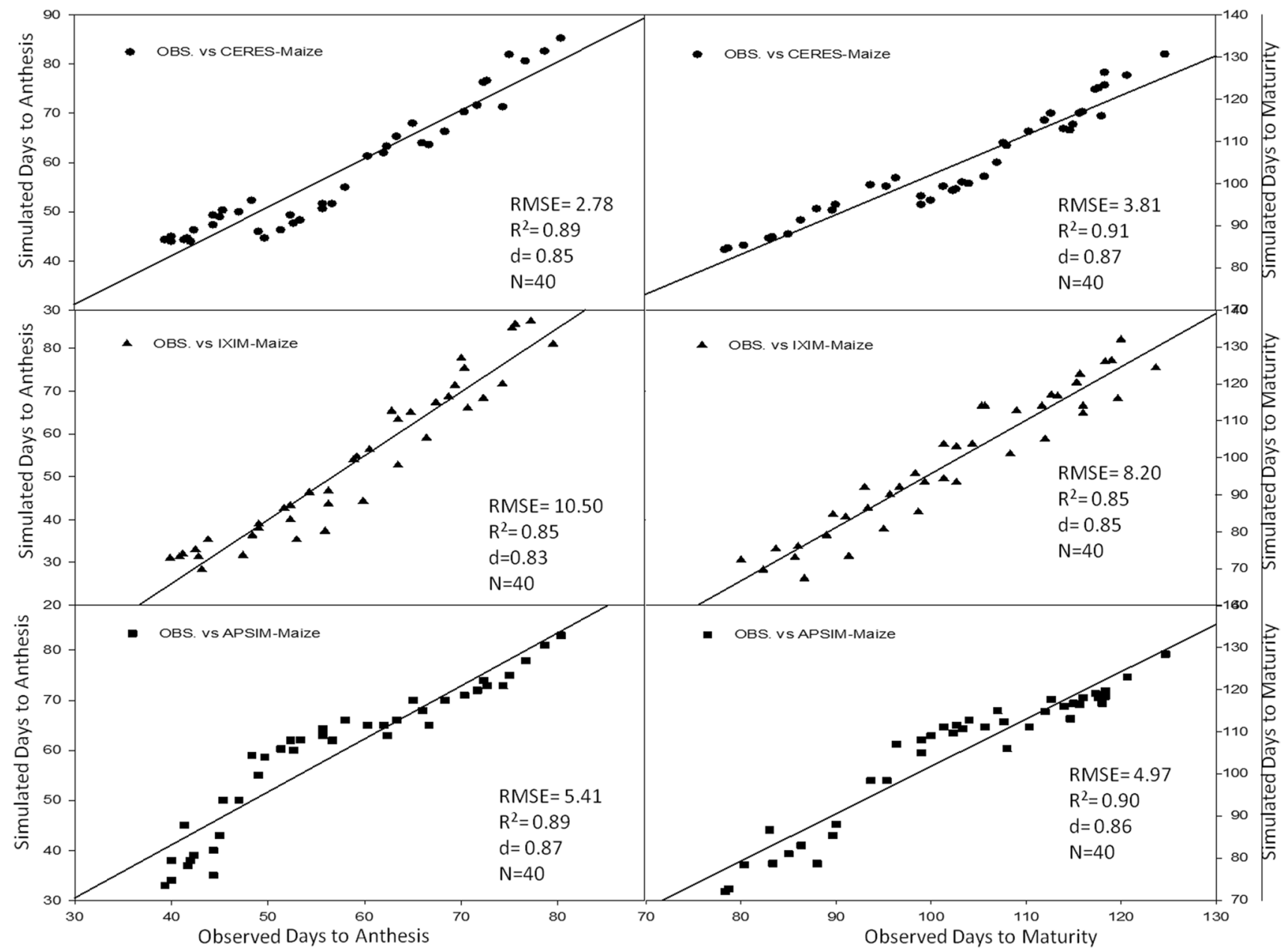

Fig. 2 Relationship between observed and simulated values of days to anthesis and days to maturity for spring maize hybrids sown at various dates during 2014-2015

\section{Climate change scenarios and uncertainty assessment for climate change impacts on maize productivity}

A significant rise in both maximum and minimum temperature and greater variability in precipitations during maize growing season in all five GCMs with the RCP 8.5 scenarios for mid-century were observed in the climate scenarios of the five GCMs (Fig. 9). Predictions from CMCC-CMS (Hot Dry scenario) showed a higher $\left(4.53{ }^{\circ} \mathrm{C}\right)$ increase in maximum temperature during mid-century, whereas NorESM1$\mathrm{M}$ (Middle) GCM predicted a lower increase by $1.57{ }^{\circ} \mathrm{C}$ in the future (2040-2069) under RCP 8.5 (Fig. 9). In the case of rainfall predictions, the IPSL-CM5A-MR (Hot Wet) GCM showed an increase $(248 \mathrm{~mm})$ in rainfall during midcentury (2040-2069), while CMCC-CMS (Hot Dry) GCM showed a minor decrease $(7 \mathrm{~mm})$ in rainfall during midcentury (Fig. 9). On average, all five GCMs predicted for minimum temperature an increase of $3.27{ }^{\circ} \mathrm{C}$ and a rise of $\left(3.29{ }^{\circ} \mathrm{C}\right)$ in maximum temperature during mid-century. A positive change with an increase of $107 \mathrm{~mm}$ was observed on an average in rainfalls during mid-century as predicted by all five climate scenarios (Fig. 9).

Variation in the changes of maximum, minimum temperature, and rainfall was observed in the outputs of the five different climate models by a mid-century period during the spring season (Figs. 10 and 11). A higher increase in maximum and minimum temperature of 5.03 and 4.99 ${ }^{\circ} \mathrm{C}$ respectively was predicted under the "Hot Dry" climate scenario (Figs. 10 and 11). Rainfall may also vary from 15 to 43 (mm) during these months (Fig. 11) as compared to other climate models. Under Cool Wet climate scenarios during mid-century a slightly lower increase was noted in maximum and minimum temperature 1.44 and $2.07{ }^{\circ} \mathrm{C}$ respectively (Figs. 10 and 11). In the simulations by all three crop models, either positive or negative impacts on maize production were observed depending on the climate scenarios. Average maize yield is expected to reduce from 440 


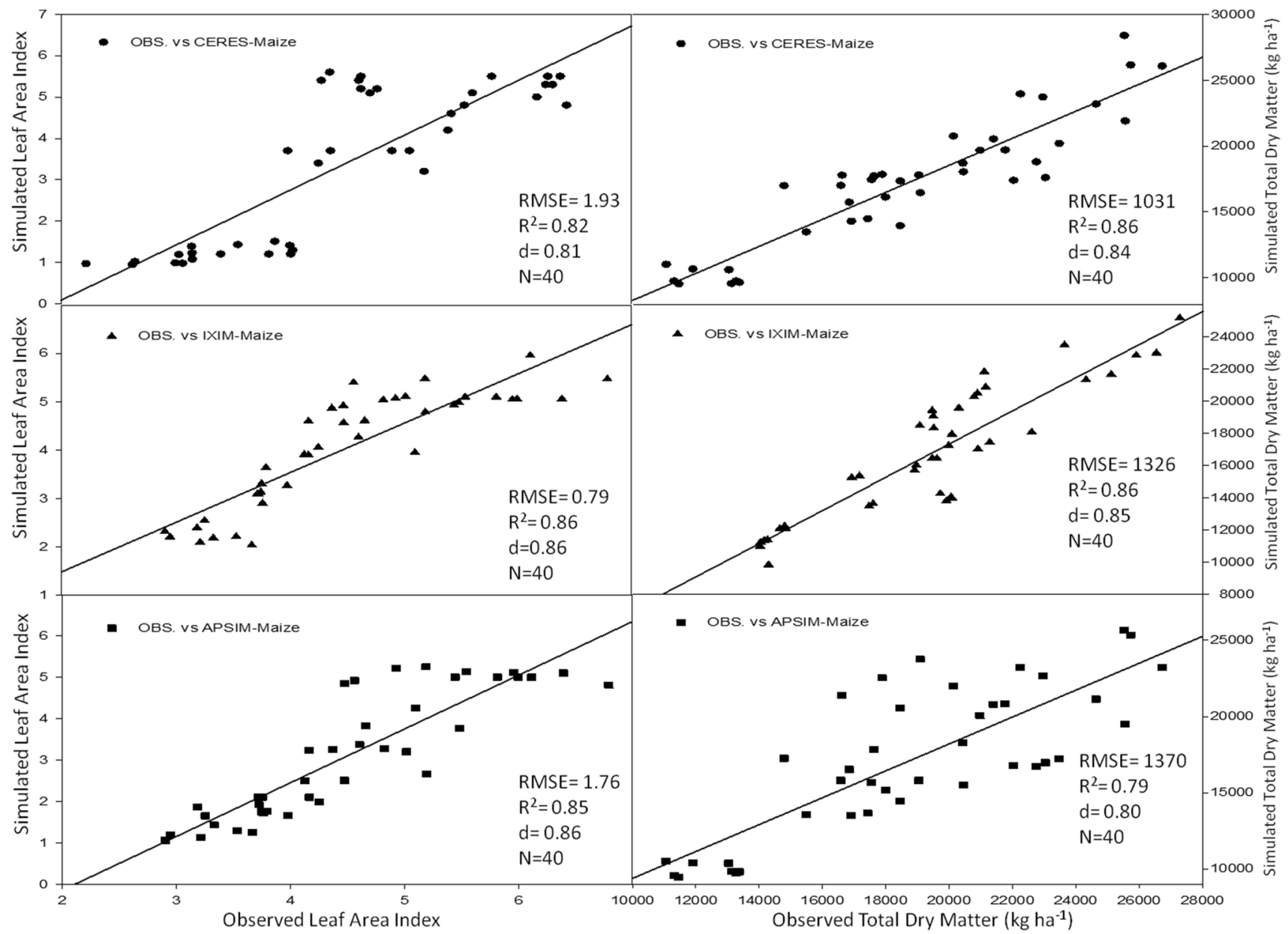

Fig. 3 Relationship between observed and simulated values of leaf area index and total dry matter $\left(\mathrm{kg} \mathrm{ha}^{-1}\right)$ for spring maize hybrids sown at various dates during 2014-2015

to $2047 \mathrm{~kg} \mathrm{ha}^{-1}$ as predicted by middle and hot wet climate scenarios during the spring season, respectively (Fig. 12). Spring season maize yield may experience a decline of up to $2047 \mathrm{~kg} \mathrm{ha}^{-1}$ from current yield under hot dry climate change scenario, while cool wet climate scenario predicted an increase $40-150 \mathrm{~kg} \mathrm{ha}^{-1}$ in yield from baseline in midcentury (Fig. 12).

Prediction of all crop models such as CERES-Maize, IXIM-Maize, and APSIM-Maize along with climate models showed a decline in yield from 8 to $55 \%$ from baseline in the spring season during mid-century, except in the "Cool Wet" scenario (Fig. 13). A very huge reduction in yield is expected up to 55\%, 50\%, and 52\% under the "Hot Dry" scenario as predicted by CERES-Maize, IXIM-Maize, and APSIM-Maize respectively. All three models indicated an increase in yield under the "Cool Wet" scenario. The CERES-Maize model predicted an average yield increase of $6-8 \%$, whereas IXIM and APSIM-Maize predicted an increase in yield from 8 to $19 \%$ in the future mid-century under cool wet climate scenarios (Fig. 13).

\section{Adaptations for spring maize crop under climate change scenarios (2040-2069)}

The calibrated maize crop models were analyzed to determine the impact of adaptation (modification in sowing date, $\mathrm{N}$ application rates, and irrigation application). The adaptation options were selected to assess their potential to alleviate the negative impacts of climate change on maize yield with the ultimate objective to get an optimum adaptation package. Fifteen (15) days earlier than the current sowing time (mid-February) performed best in all GCMs than other planting dates (Fig. 14).

Three nitrogenous fertilizer levels $(10 \%, 20 \%$, and $30 \%)$ increased from recommended nitrogen rate applied in three splits@220 kg ha ${ }^{-1}$ in this study were tested along with the sowing date to develop combined adaptation practice for future climate. An increase in $20 \%$ of nitrogen fertilizer application then-current rate sustained the maximum grain yield of maize when planted early in the spring season. A similar above-mentioned practice was repeated for 


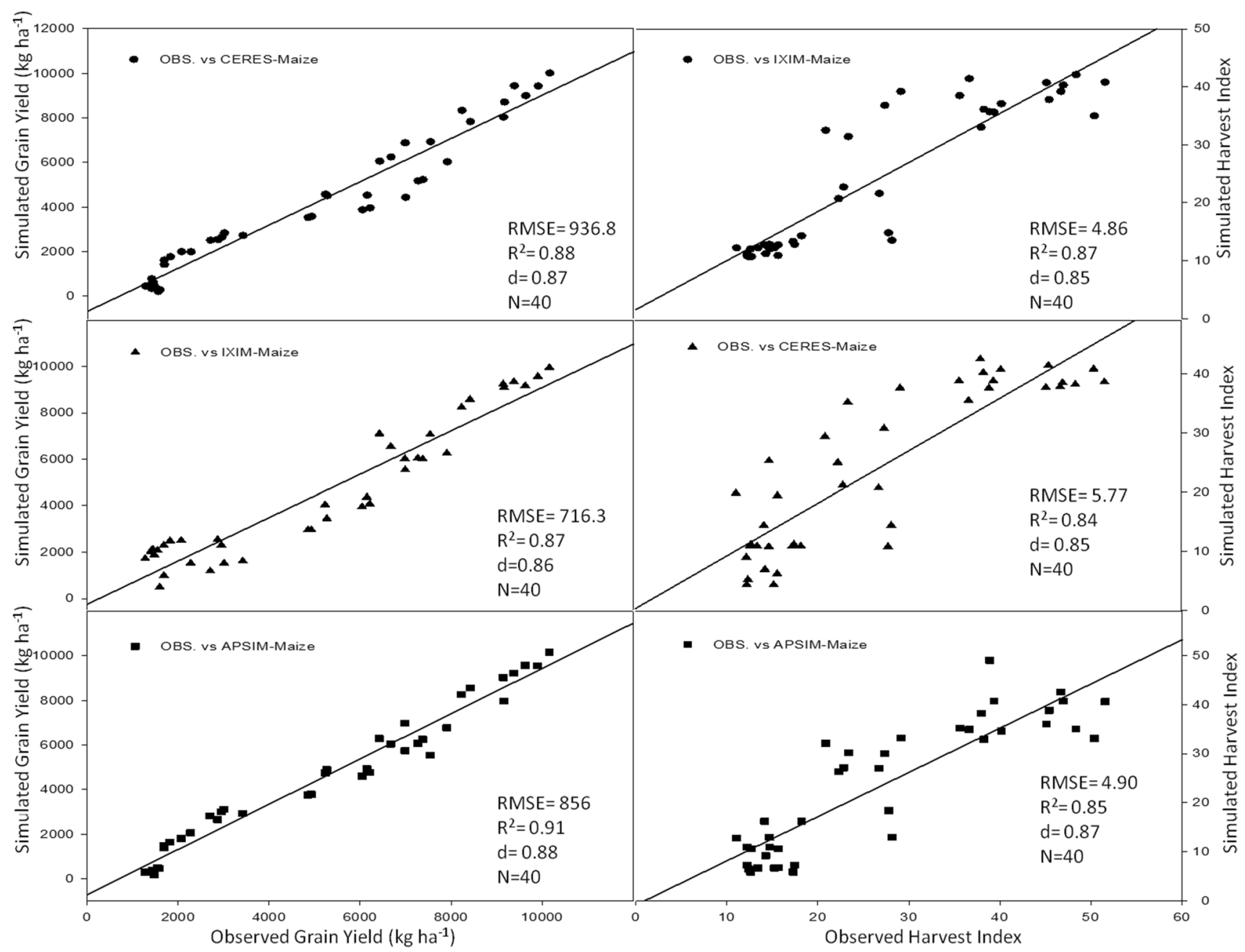

Fig. 4 Relationship between observed and simulated values of grain yield $\left(\mathrm{kg} \mathrm{ha}^{-1}\right)$ and harvest index for spring maize hybrids sown at various dates during 2014-2015

determining the irrigation adaptation. Irrigation treatments $80 \%$ and $90 \%$ of $100 \%$ full irrigation (recommended) were tested in which $90 \%$ of irrigation was found as a good adaptation practice to get maximum yield return (Fig. 15). These practices may act as a good production package to obtain maximum maize productivity under mid-century climatic scenarios as predicted by all crop and climate models.

\section{Discussion}

Using crop growth models for the determination of crop growth, yield, and developmental phases at different sowing dates is a very helpful technique for various climatic conditions. The researcher used modeling techniques to get assistance in developing the information regarding the short-term and long-term organization of agricultural activities (Aurbacher et al. 2013). Multi-models may have different simulating behavior under various environmental conditions such as a series of sowing times. In the current study, the performance of three maize models (CERESMaize, IXIM-Maize, and APSIM-Maize) was tested at various sowing dates and hybrids. The genetic coefficients for DK-6103, NK-8711, P-1543, FH-1898 were well-calibrated in all crop models (Tables 1 and 2). Genetic coefficients of DSSAT modules and APSIM-model were variate as previously reported (Knorzer et al. 2011; Kassie et al. 2014). The genetic coefficient may vary among hybrids and also due to climatic conditions (Araya et al. 2015). All models simulated crop phenology, growth, and yield very well with satisfactory mean percent difference values during the process of calibration of models (Table 3). For phenological attributes, APSIM-Maize and CERES-Maize models predicted lesser mean percent difference as CERES-Maize and APSIM-Maize model showed days to anthesis and days to maturity with lower RMSE values (2.78 and 5.41), higher 

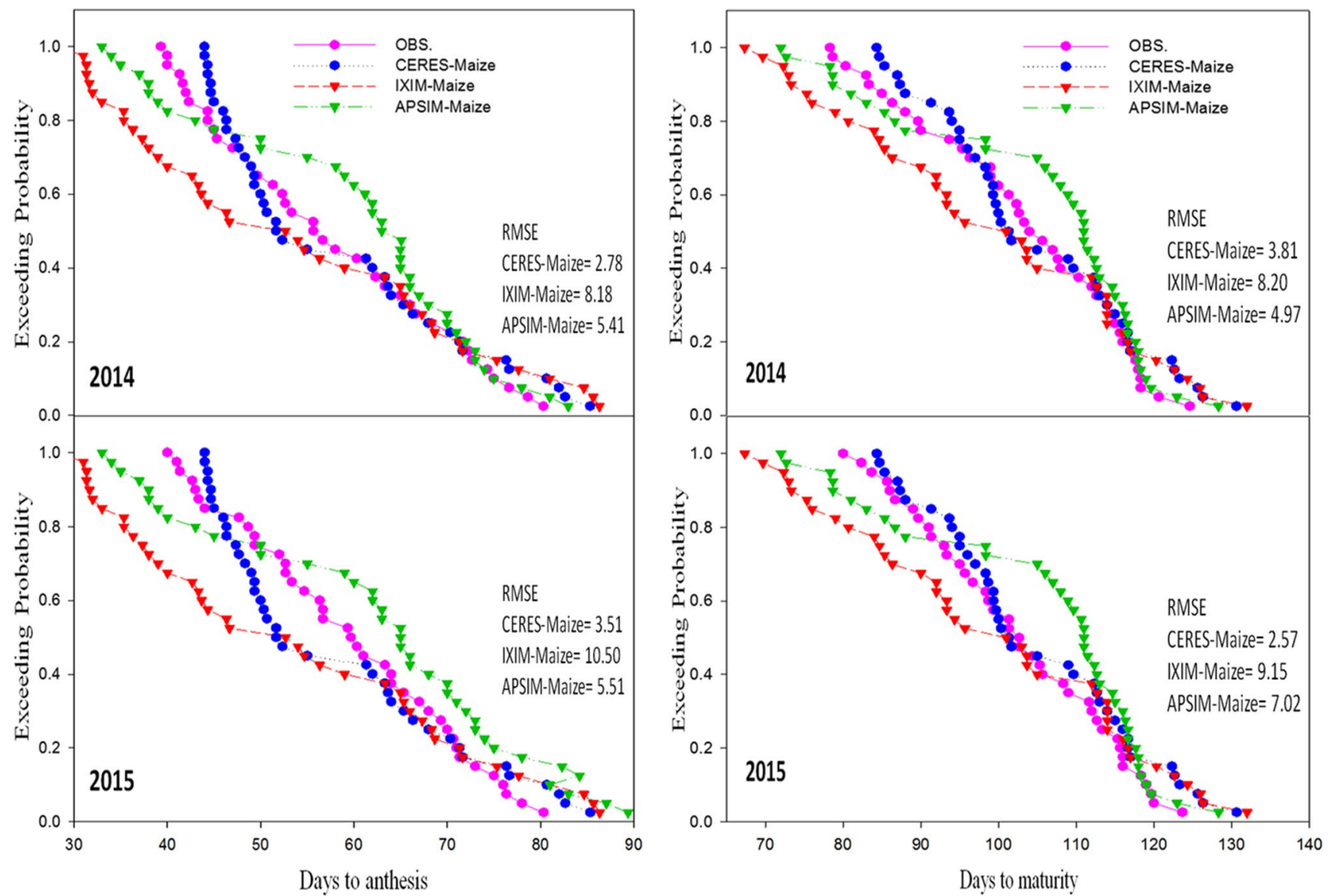

Fig. 5 Simulating behavior of Maize multi-models for days to anthesis and days to maturity of spring hybrid maize during 2014-2015

$d$-index (0.85 and 0.87) along with fair $R^{2}(0.89$ and 0.89$)$ respectively (Fig. 2). Similar results were reported by Mubeen et al. (2016) and Ban et al. (2015) that the CERESMaize model simulated maize phenology very well with less difference between simulated and observed values under a semi-arid environment. Chenu et al. (2009) reported that the APSIM-Maize model predicted maize phenology and yield very well with less mean percent difference during the maize growing season. The CSM-IXIM-Maize model performed well for leaf area index and total dry matter with less RMSE (0.79 and 1326), good $d$-index (0.86 and 0.85) respectively, and fair $R^{2}$ value (0.86) compared to the other two models (Fig. 3). The CSM-IXIM-Maize model simulates the leaf area index of the plant very accurately as it modified from CERES-Maize model with few improvements (Ban et al. 2015). The CSM-IXIM-Maize model performed well for grain yield $\left(\mathrm{kg} \mathrm{ha}^{-1}\right)$, with less RMSE (716.3), high $d$-index (0.88), and acceptable $R^{2}$ value (0.87) compared to the other two models, whereas CERES-Maize and APSIMMaize showed better predictions for harvest index with lower RMSE (4.86), $d$-index (0.87), and reliable $R^{2}$ value (0.85) (Fig. 4). Simulations of the CSM-IXIM-Maize are very efficient for total dry matter assimilation and partitioning and grain yield (Lizaso et al. 2011). CERES-Maize, CSMIXIM-Maize, and the APSIM-Maize could be used under different climates for simulation studies and mounting crop management activities (Hoogenboom et al. 2011; Holzworth et al. 2014).

Simulating the behavior of maize multi-models (CERESMaize, CSM-IXIM-Maize, and APSIM-Maize) exhibited a reliable relationship between observed and simulated values for all recorded attributes. The CERES-Maize and APSIMMaize model predicted maize phenology such as days to anthesis and days to maturity with lower RMSE (2.78 and 5.41), higher $d$-index (0.85 and 0.87) along with fair $R^{2}(0.89$ and 0.89 ) respectively (Fig. 2). These results seem similar to the findings of Soler et al. (2007), Tojo et al. (2007), and Gaydon et al. (2017) which reported that CERES-Maize model and APSIM-Maize can predict days to anthesis of maize very closely under different environments. The CSMIXIM-Maize model performed well with a close prediction for lead area index, total dry matter $\left(\mathrm{kg} \mathrm{ha}^{-1}\right)$, and grain yield $\left(\mathrm{kg} \mathrm{ha}^{-1}\right)$ (Figs. 6 and 7). The CSM-IXIM-Maize can simulate biomass and grain yield of maize accurately (Yakoub et al. 2017). The APSIM-Maize simulation for the total dry matter was good with lower RMSE values 

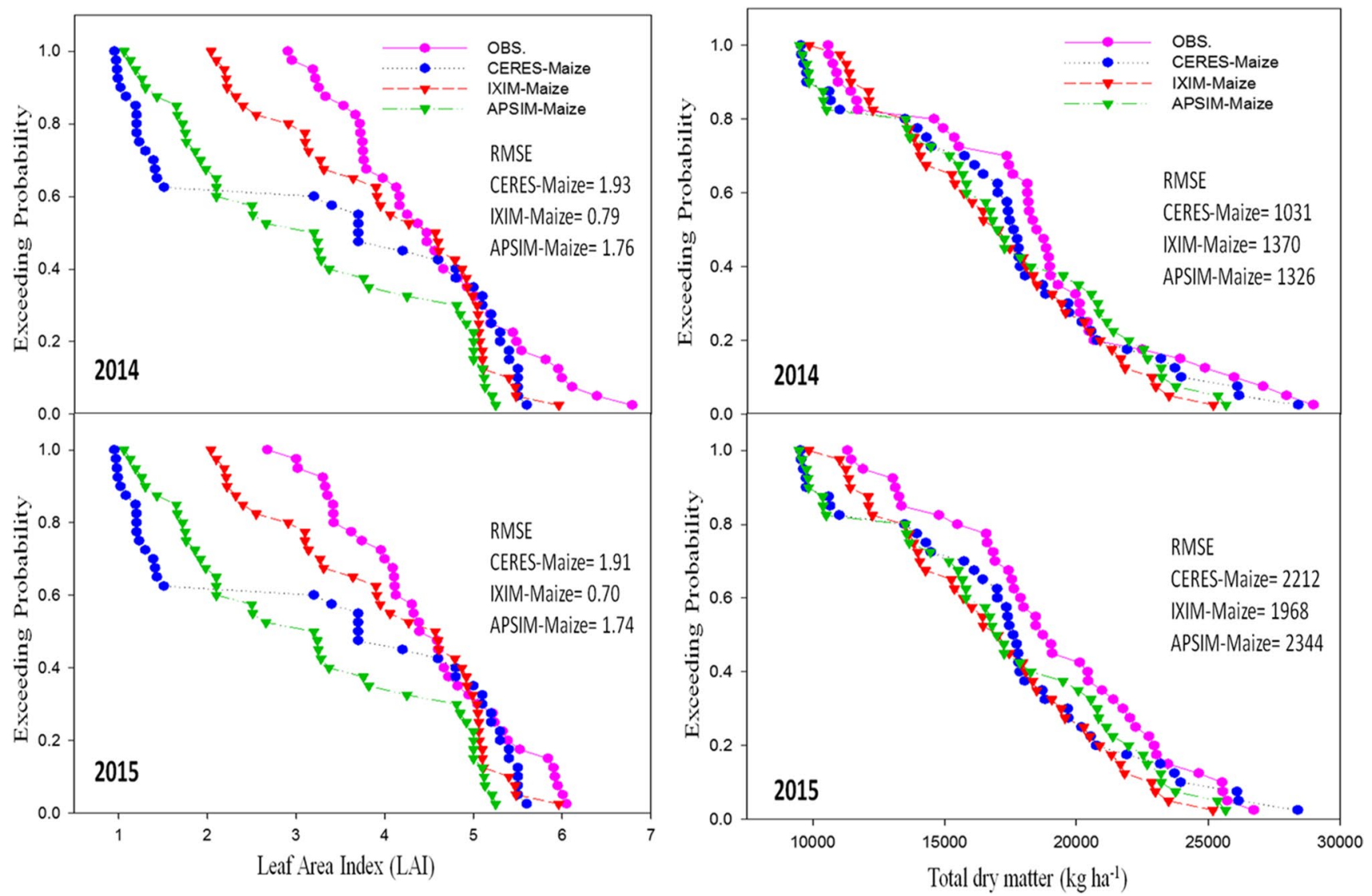

Fig. 6 Simulating behavior of Maize multi-models for leaf area index (LAI) and total dry matter $\left(\mathrm{kg} \mathrm{ha}^{-1}\right)$ of spring hybrid maize during 20142015

during both years (Fig. 6) which is similar to the findings of Knorzer et al. (2011).

Increasing temperature and fluctuations in precipitation and drought spells are likely to decrease crop productivity in the future (Kang et al. 2009). Global general circulation models (GCMs) are well-known for their projections regarding future climates and predicted the rise in global temperature from 1.6 to $4.6{ }^{\circ} \mathrm{C}$ in the next 50 to 100 years due to high emissions of greenhouse gases (IPCC 2007). Climate change impact assessment studies may not rely upon a single GCM. The use of multiple models may be an efficient method for climate change impact assessment and its vulnerability to crop productivity (Rosenzweig et al. 2013; Asseng and Ewert 2013). Pakistan is highly susceptible to the adverse impacts of climate change. Due to extreme climatic conditions, crop productivity was negatively affected. The projected decline in major crop yield in the future is from 0.8 to $27 \%$ from the current yield. Climate change impact assessment studies and adaptation packages are required to reduce these negative effects. Rasul and Ahmad (2012) reported that the average annual temperature has increased from 0.6 to $1{ }^{\circ} \mathrm{C}$ during the past 50 years. Ahmad et al. (2015) reported an average rise in mean annual temperature from 2 to $3{ }^{\circ} \mathrm{C}$ as compared to the baseline during the midcentury RCP 8.5 scenario, and rainfall may have unexpected fluctuations either increase or decrease as compared to the current rainfall pattern. These results match with the results of the current study that there would be a rise in temperature from 1.57 to $3.29{ }^{\circ} \mathrm{C}$ and enormous fluctuations in rainfall during maize growing seasons in all five GCMs with RCP 8.5 scenarios for the mid-century (Fig. 9). Results from current climate change studies showed that there would be a temperature rise either maximum or minimum and greater variability in precipitations during maize growing season in all five GCMs for the mid-century (Fig. 9). The CMCCCMS (Hot Dry) climate scenario and NorESM1-M (Middle) predicted a higher $\left(4.53{ }^{\circ} \mathrm{C}\right)$ and $1.57^{\circ} \mathrm{C}$ change/increase in maximum temperature respectively during mid-century (2040-2069) under RCP 8.5. Similar to the results reported by Iqbal and Zahid (2014), in Pakistan there would be a rise up to $4.38{ }^{\circ} \mathrm{C}$ in the future. On average, all five GCMs predicted a high increase $\left(3.27^{\circ} \mathrm{C}\right)$ in minimum temperature and an increase of $3.29^{\circ} \mathrm{C}$ in maximum temperature during mid-century (Fig. 9) that would have quite negative effects on maize productivity. Ishfaq et al. (2020) reported that maximum and minimum temperature would increase 

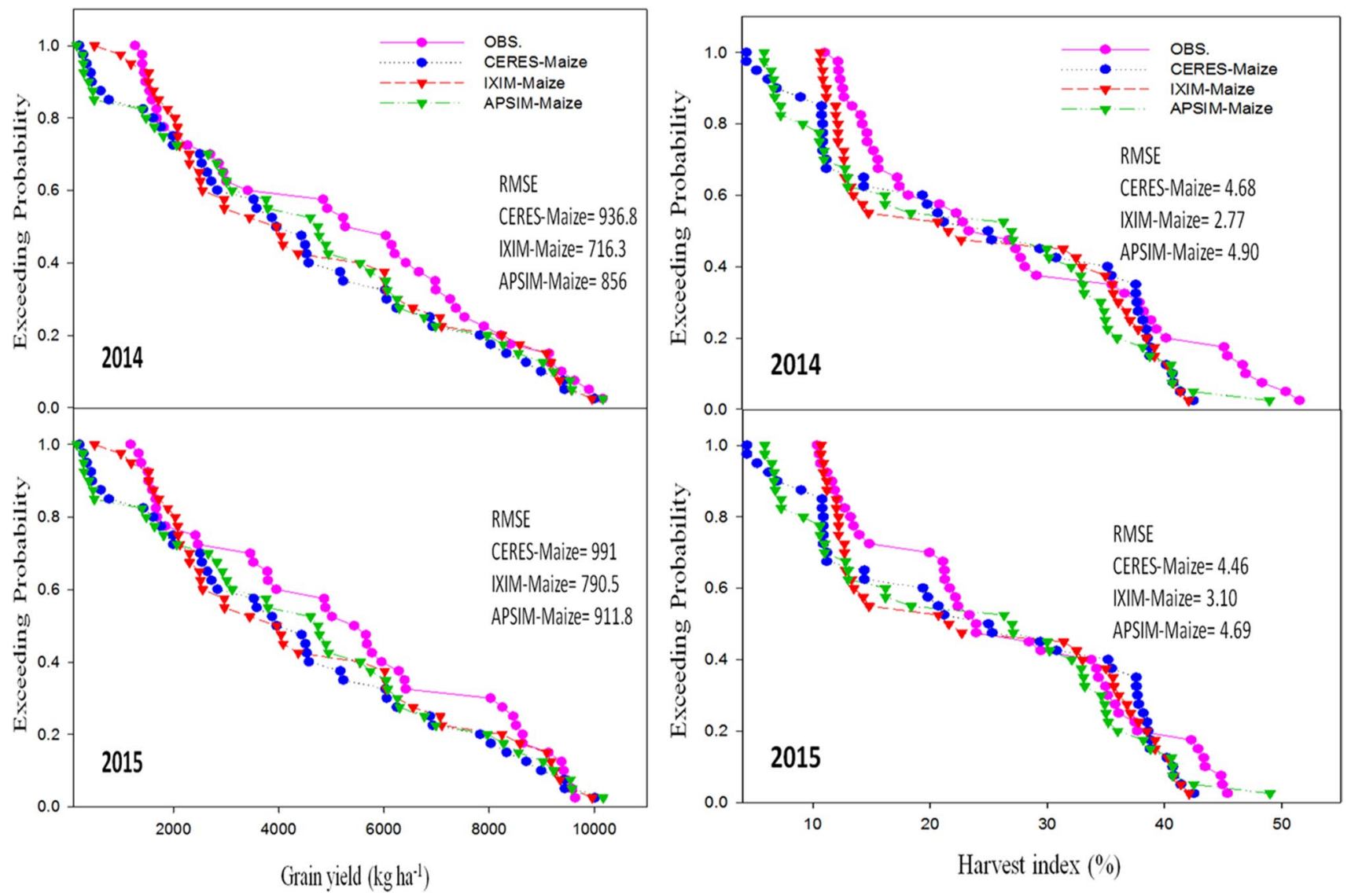

Fig. 7 Simulating behavior of Maize multi-models for grain yield $\left(\mathrm{kg} \mathrm{ha}^{-1}\right)$ and harvest index of spring hybrid maize during 2014-2015

Fig. 8 Performance efficiency of CERES, IXIM, and APSIM Maize multi-models during spring 2014-2015

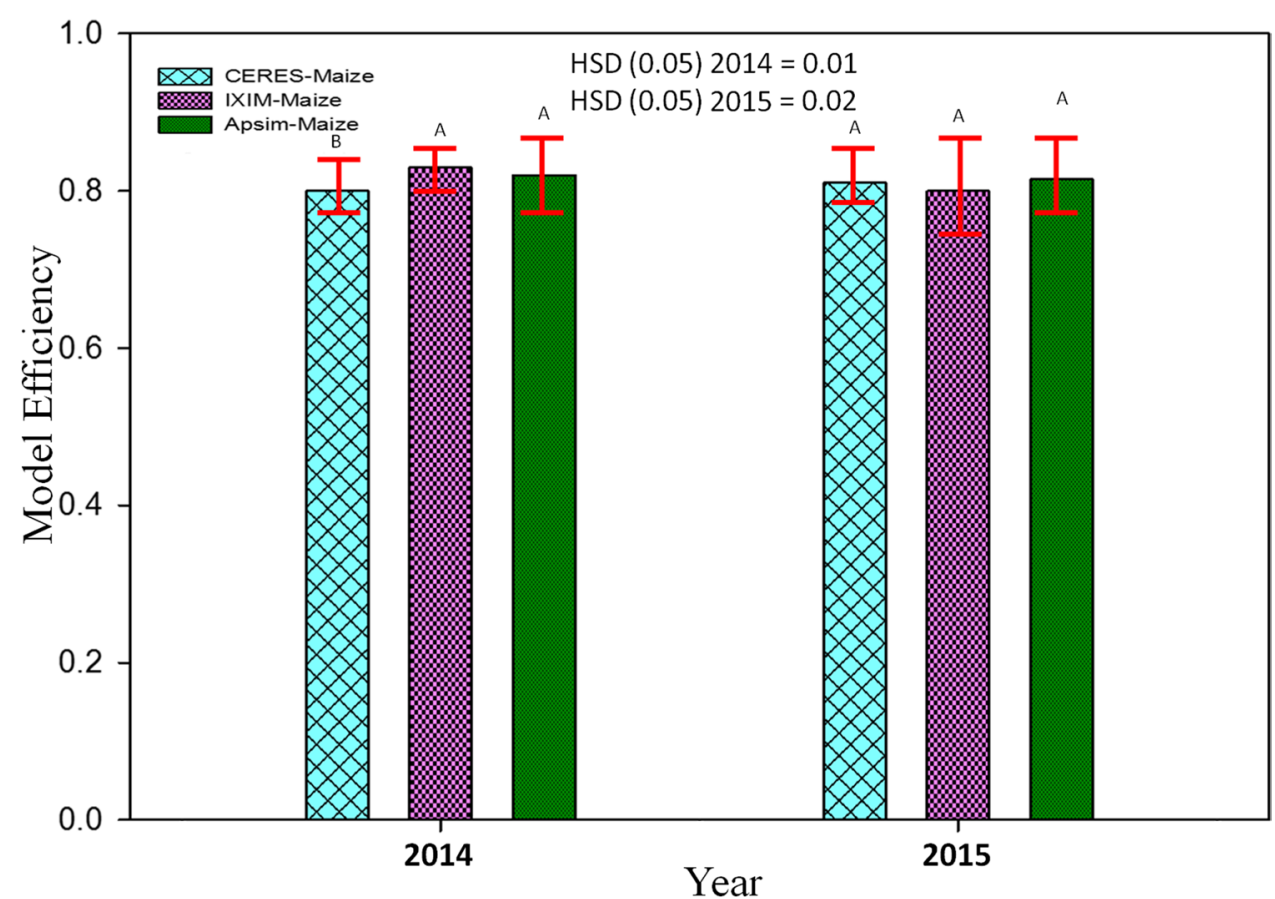



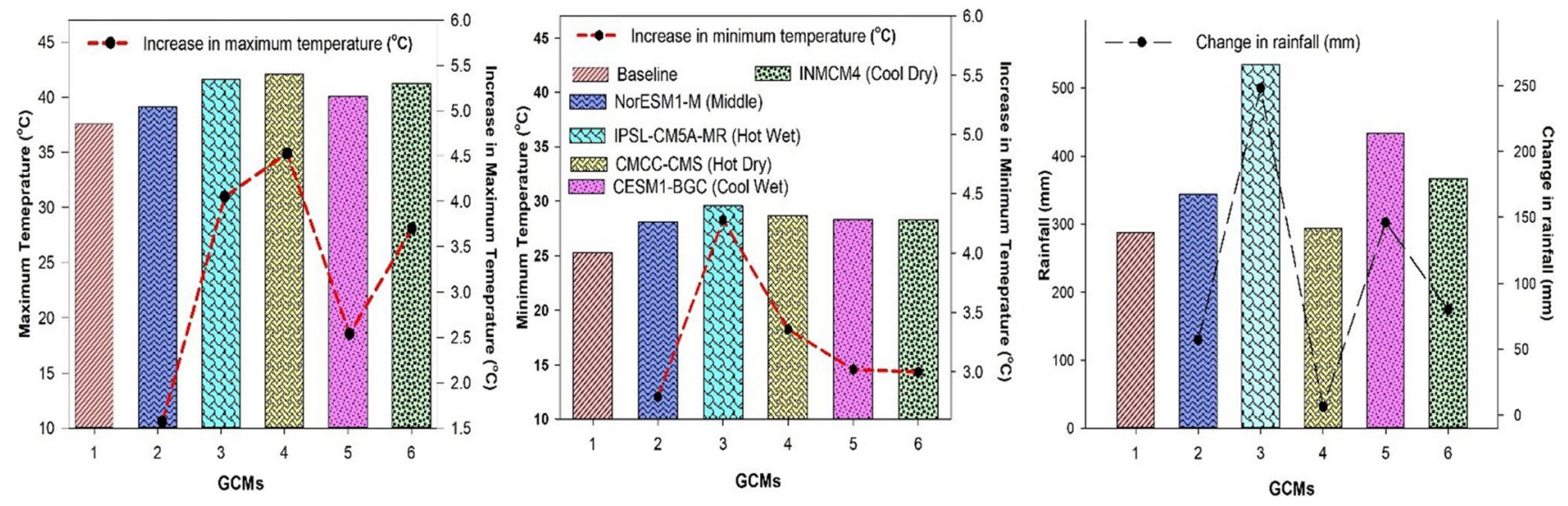

Fig. 9 Predicted change in climatic variables by the period 2040 to 2060 for five climate models (GCMs) compared to the baseline period

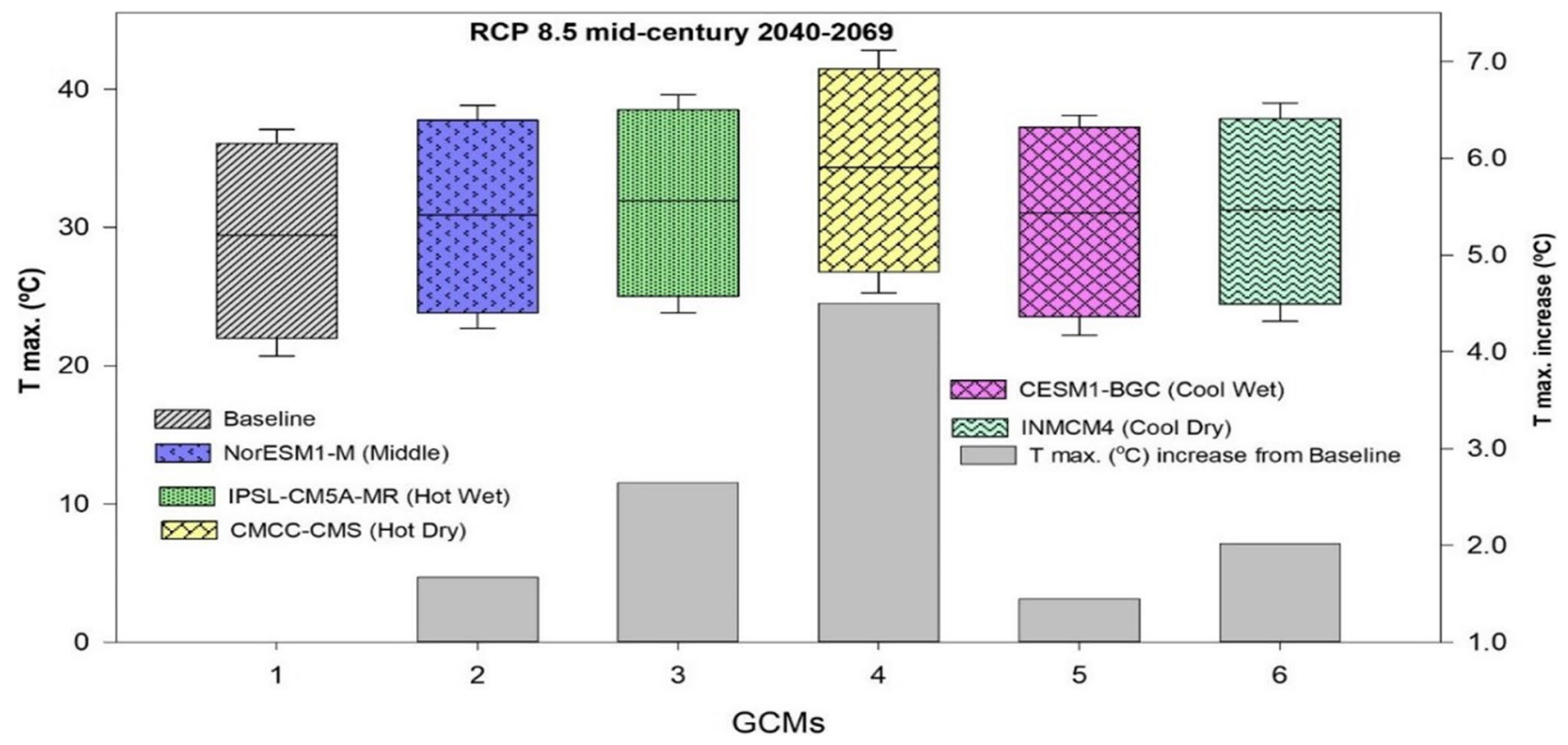

Fig. 10 Predicted change in monthly mean maximum temperature $\left({ }^{\circ} \mathrm{C}\right)$ during the spring season (February, March, April, May) in future (2040-2069) under representative concentration pathways (RCPs) 8.5

through selected GCMS. *(1=baseline, 2=NorESM1-M, 3= IPSLCM5A-MR, 4= CMCC-CMS, 5= CESM1-BGC, and 6= INMCM4)

from 3.4 to $3.8{ }^{\circ} \mathrm{C}$ by mid-century under RCP 8.5 . IPSLCM5A-MR (Hot Wet) GCM predicted a very high (248 mm) fluctuation in rainfall during mid-century (2040-2069), and CESM1-BGC (Cool Wet) GCM showed a change of 146 $\mathrm{mm}$ in rainfall during mid-century (Fig. 9). High temperature enhances the evaporative rate from the earth's surface due to which hot air becomes moist and more rainfall occurs as a similar phenomenon was reported by Trenberth (2011). The average change of $107(\mathrm{~mm})$ in rainfalls during mid-century (2040-2069) was predicted by five different climate scenarios (Fig. 8). Climate change impacts could reduce average maize yield up to $25 \%$ by 2050 under changing climate in the future (Ishfaq et al. 2020). The climate models along with crop models help scientists to estimate changes in yields and other parameters. The final yields capture the influence of GCMs, the interactions between soil, climate, and crop management (Islam et al. 2016). Bassu et al. (2014) reported that the multi-model approach is more efficient than one single model in determining mean yield while having very limited data for model calibration. In the current study, variations in the performance of five GCMs on maize yield along with three maize models (CERES-Maize, IXIM-Maize, and APSIM-Maize) were observed (Fig. 13). Spring season average maize yield is expected to decline $440 \mathrm{~kg} \mathrm{ha}^{-1}, 770 \mathrm{~kg} \mathrm{ha}^{-1}, 1538 \mathrm{~kg} \mathrm{ha}^{-1}$, and $2047 \mathrm{~kg} \mathrm{ha}^{-1}$, predicted by middle, hot wet, cool dry, and hot dry climate 


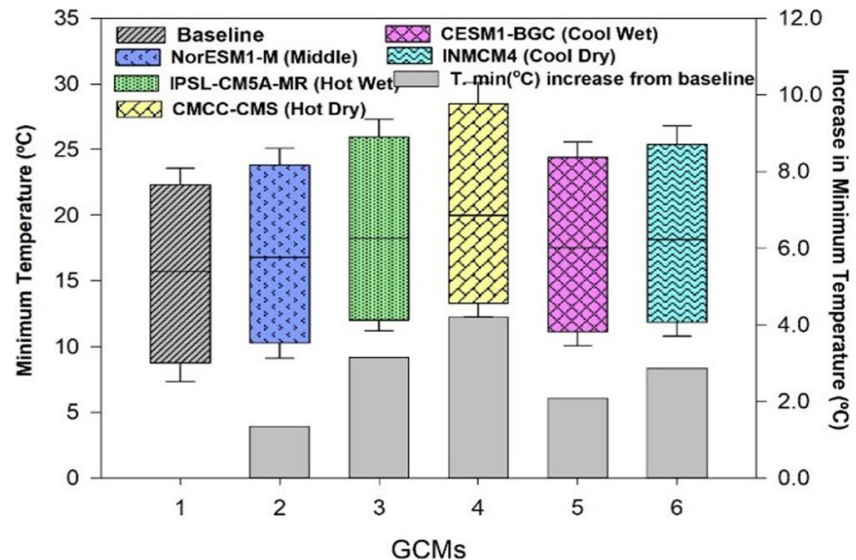

Fig. 11 Predicted change in monthly mean minimum temperature $\left({ }^{\circ} \mathrm{C}\right)$ and rainfall $(\mathrm{mm})$ during the spring season (February, March, April, May) in future (2040-2069) under representative concen-

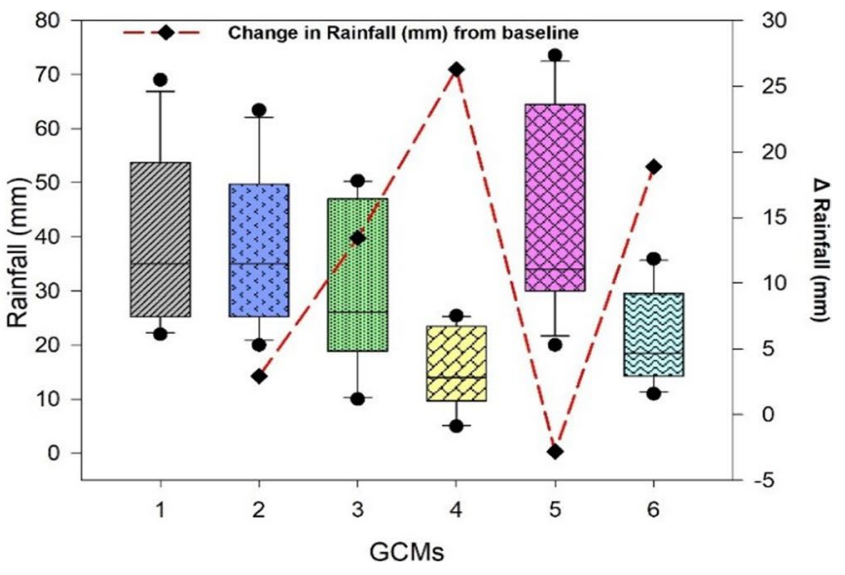

tration pathways (RCPs) 8.5 through selected GCMs. $*(1=$ baseline, 2=NorESM1-M, 3= IPSL-CM5A-MR, 4= CMCC-CMS, 5= CESM1-BGC, and 6= INMCM4)
Fig. 12 Impact of climate change on spring (February, March, April, May) maize planting under different climate change scenarios

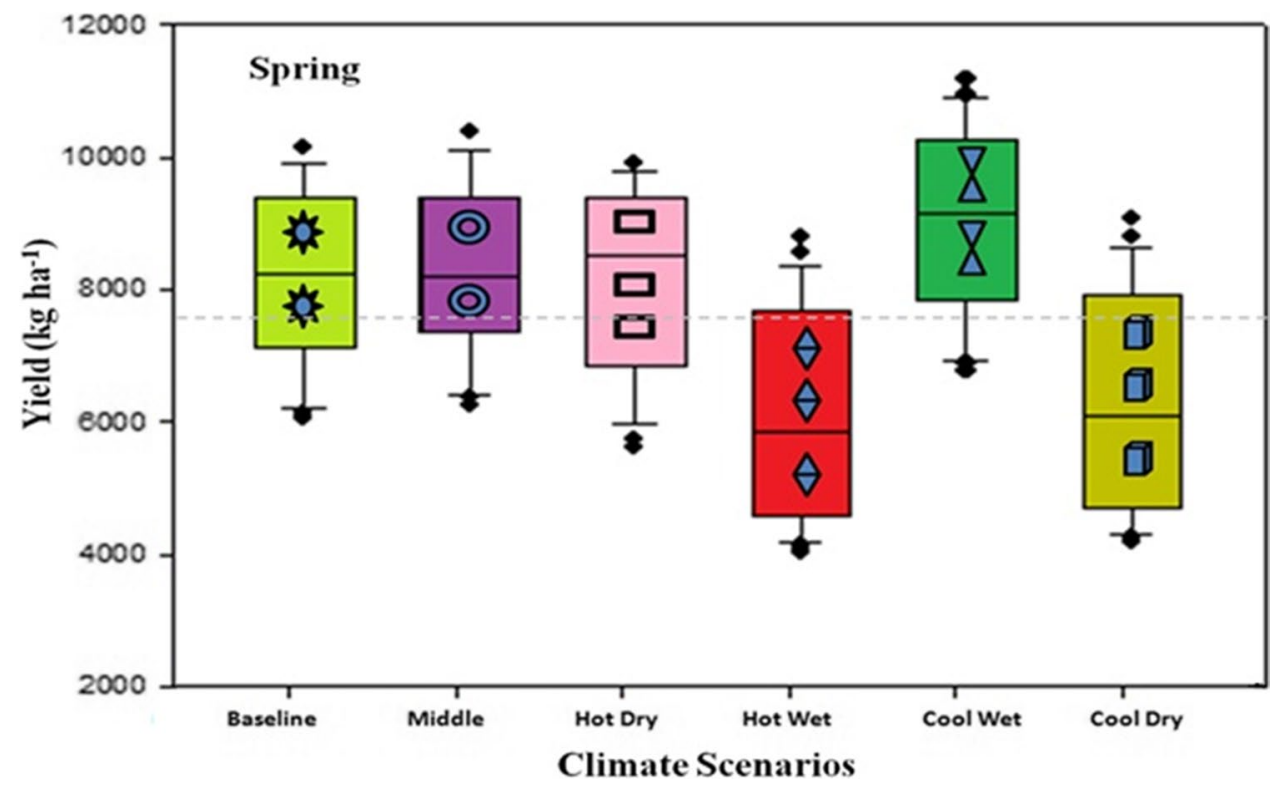

scenarios (Fig. 12). The decline in yield might be due to the phenomenon reported by Bassu et al. (2014) that high temperatures increased the development rate as a result of the duration of growth and developmental phases reduced. All three crop models (CERES-Maize, IXIM-Maize, and APSIM-Maize) predicted up to an $8-55 \%$ yield decline from baseline yield in spring yield during mid-century (Fig. 13). This decline in yield would be due to an increase in temperature. The CERES-Maize model showed 6-8\% average increase in yield, while IXIM and APSIM-Maize presented an increase of yield from 8-19\% during mid-century under cool wet climate scenarios (Fig. 13). These results are in line with the results of Dimes et al. (2003) and Chen et al. (2012) which reported that APSIM performed well under changing climate scenarios. Maize yield may slightly increase from the baseline under sub-humid climate whereas decreased under semi-arid conditions (Araya et al. 2015). Pandey et al. (2007) noticed that rising temperature had reduced (8 to $31 \%$ ) the maize yield by using DSSAT. The Agricultural Model Inter-comparison and Improvement Project (AgMIP) maize model inter-comparison project studies found large variations among multiple maize model yield predictions (Bassu et al. 2014). Climate change impacts on maize yields for most important climate scenarios range between -20 and $-45 \%$ for maize by 2100 (Müller and Elliott 2015). The above-mentioned decline in yield is due to increased temperature and less rainfall causing huge losses to the farming community.

Adaptation strategies are necessary to cope up with the hazardous effects of climate change in the future. Modifying 

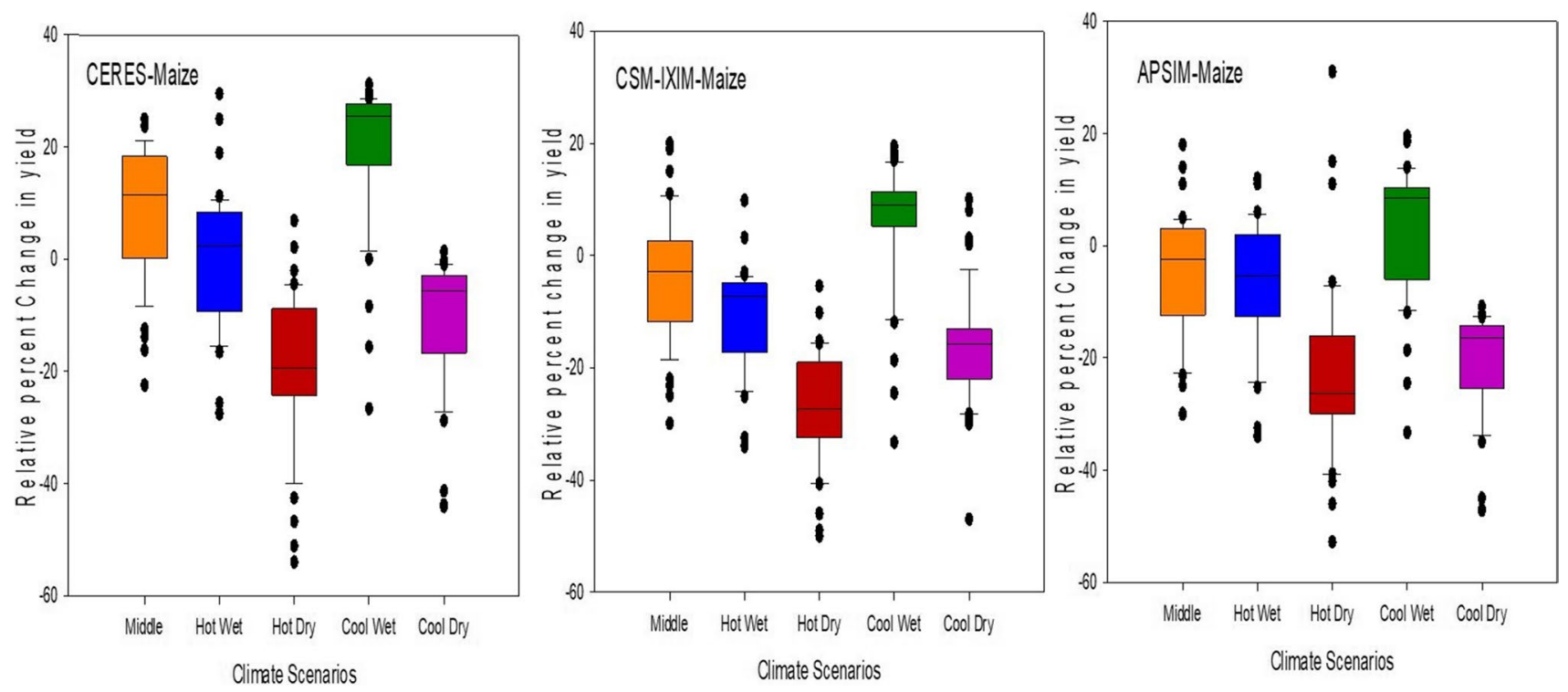

Fig. 13 Relative change in grain yield in response to future climate (2040-2069) during spring with three crop models under five climate scenarios
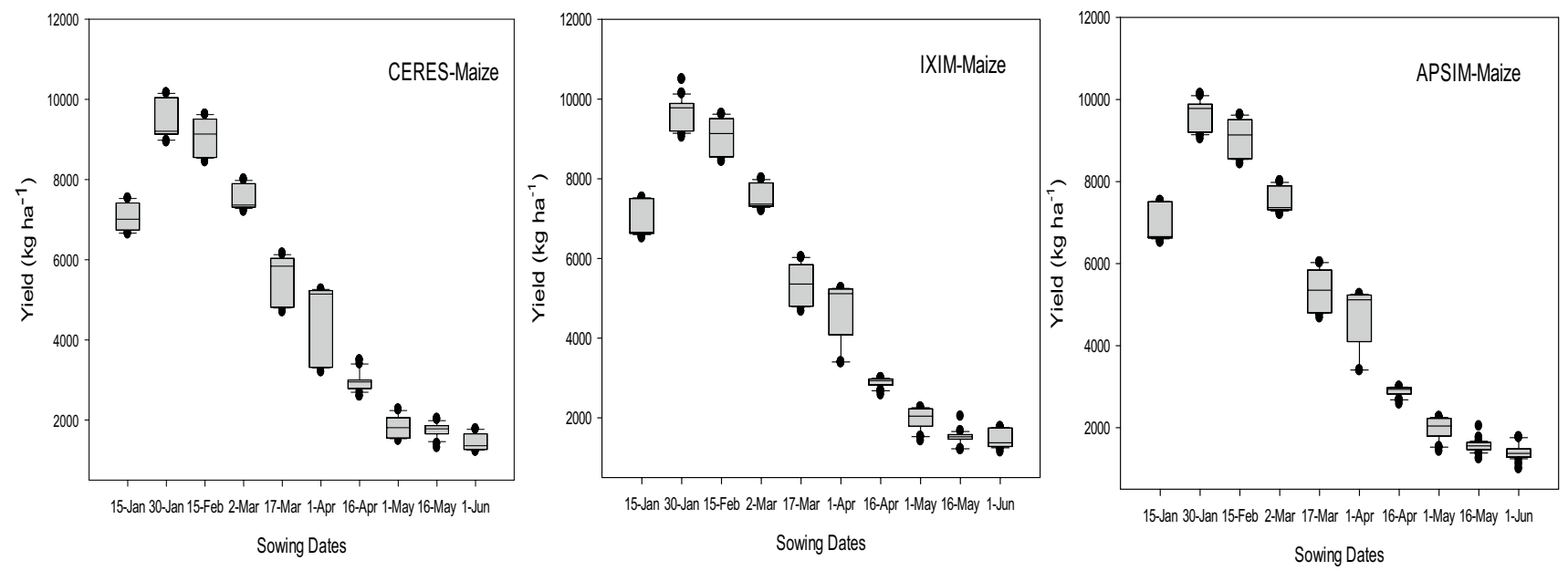

Fig. 14 Effect of sowing dates on grain yield $\left(\mathrm{kg} \mathrm{ha}^{-1}\right)$ in response to future climate (2040-2069) during spring crop season with three crop models

the management practices such as sowing dates, varying fertilizer rates, irrigation applications (Figs. 14 and 15) and enhancing the genetic potential of cultivars could be beneficial for increasing maize productivity in future climate change scenarios. Maize crop models (CERES-Maize, CSM-IXIM-Maize, APSIM-Maize) predicted higher net return in terms of yield $\left(\mathrm{kg} \mathrm{ha}^{-1}\right)$ when maize is planted at sowing date (30 January) for all five GCMs during midcentury RCP 8.5. Fifteen (15) days earlier sowing of maize has a bigger yield potential than the current sowing time (mid-February). It could be a better planting time during mid-century than other planting dates (Fig. 14). While at this planting date (30 January) in combination with $20 \%$ more fertilizer and $90 \%$ efficiency of irrigation practice can give 20-30\% higher yield than the current sowing time (Fig. 15). The crop production enhanced when the rate of nitrogenous fertilizer increased from the recommended as presented in previous studies (Wajid et al. 2010). Similarly, Deb et al. (2014) reported that by modifying the sowing dates, then the current dates may increase yield from 5 to $22.5 \%$ in the future. It might be due to an extension in the growing and grain filling period when planted earlier than the current planting date as mentioned by Lv et al. (2019). Amin et al. (2018) recommend the moderate use of fertilizer doses to 

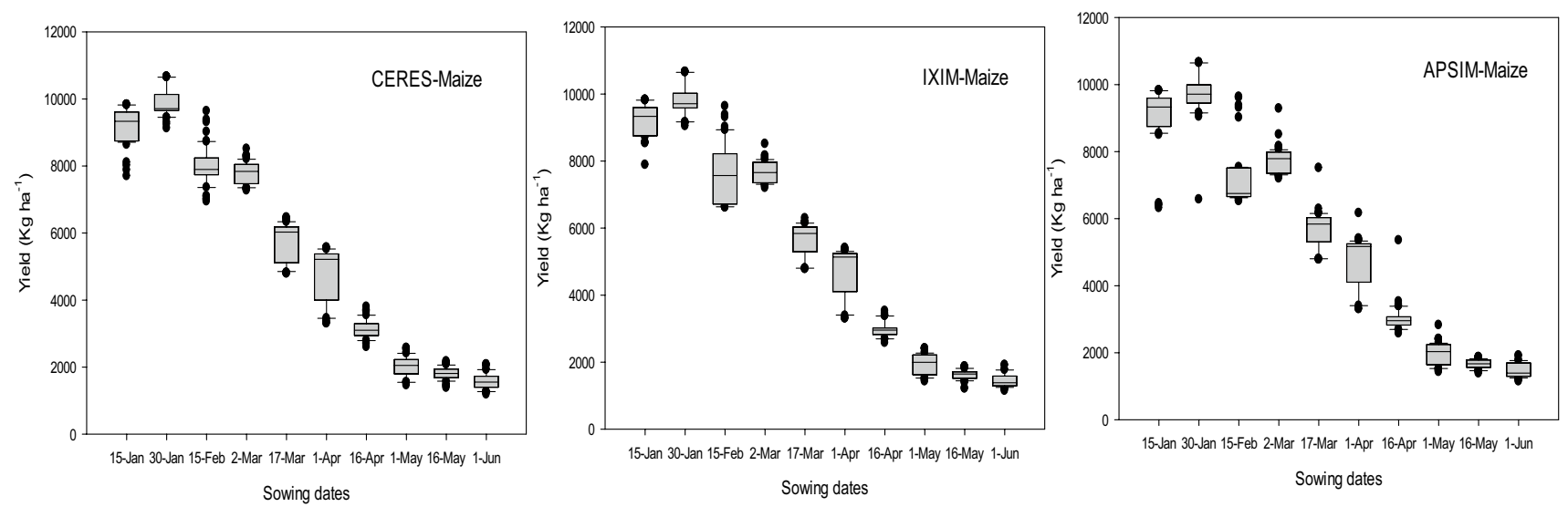

Fig. 15 Effect of sowing dates in combination with varying fertilizer and irrigation practices on grain yield $\left(\mathrm{kg}^{-1}\right)$ in response to future climate (2040-2069) during spring crop season with three crop models

avoid the potential threats of a future changing climate. Further, there is a need to test adaptation technology in the field and controlled conditions by providing future climate projections.

\section{Conclusions}

Changing climate adversely affects agricultural productivity and creates food insecurity. Crop growth models are modern and efficient tools that have been extensively used in mounting the climate change impacts and developing adaptation packages for sustainable crop production under changing climate. Based on the findings of this study, it is concluded that all three models (CERES-Maize, IXIM-Maize, and APSIM) performed reasonably well for spring plantation and could be used under arid to semi-arid climatic conditions. Simulating behavior and performance of CERES-Maize and APSIM-Maize for phenological events was good, whereas CSM-IXIM-Maize simulations for leaf area index, biomass, and yield were found well during both studied years. Keeping in view the climate change impacts, there would be a rise in temperature $1.57-3.29{ }^{\circ} \mathrm{C}$ and variations in rainfall during maize growing season in all five GCMs with RCP 8.5 scenarios for the mid-century (2040-2069). Maize models (CERES-Maize, IXIM-Maize, and APSIM-Maize) predicted up to an $8-55 \%$ yield decline from baseline yield for all GCMs in spring yield during mid-century. In the spring season, early plantations may be beneficial to get a higher yield. Hybrid FH-1898, being a late-maturing hybrid, will get the benefit for yield when sown earlier in spring. P-1543 and 30-Y-87 are short-duration and high-yielding hybrids for the current production system, respectively. Climate change is negatively affecting current and future maize production systems, but these negative effects on crop production can be minimized through following management and adaptation strategies like modifying the planting dates (30 January in spring than mid-February) and $20 \%$ increase in nitrogen fertilizer, together with $90 \%$ irrigation (fertigation) and development of heat and drought-tolerant hybrids.

Author contribution Conceptualization, A.A., M.Y., and T.K.; methodology, M.Y., H.S. H., and M.H.R.; software, M.Y. and M.H.R.; validation, A.A. and T.K.; formal analysis, M.Y. and M.H.R.; investigation, G.H. and S.N.; resources, A.A. T.K.; writing-original draft preparation; M.Y., and M.H.R.; writing-review and editing, T.G., I.G. M.Q., G.H, and M.H.R. All authors have read and agreed to the published version of the manuscript.

Funding Open Access funding enabled and organized by Projekt DEAL. APC has been paid by INRES, University of Bonn, Germany.

Data availability The datasets used and/or analyzed during the current study are available from the corresponding author on reasonable request.

\section{Declarations}

Ethics approval and consent to participate We all declare that manuscript-reporting studies do not involve any human participants, human data, or human tissue. Therefore, it is not applicable.

Consent for publication Our manuscript does not contain data from any individual person, so it is "Not applicable."

Competing interests The authors declare no competing interests.

Open Access This article is licensed under a Creative Commons Attribution 4.0 International License, which permits use, sharing, adaptation, distribution and reproduction in any medium or format, as long as you give appropriate credit to the original author(s) and the source, provide a link to the Creative Commons licence, and indicate if changes were made. The images or other third party material in this article are included in the article's Creative Commons licence, unless indicated otherwise in a credit line to the material. If material is not included in the article's Creative Commons licence and your intended use is not 
permitted by statutory regulation or exceeds the permitted use, you will need to obtain permission directly from the copyright holder. To view a copy of this licence, visit http://creativecommons.org/licenses/by/4.0/.

\section{References}

Abbas G, Ahmad S et al (2017) Quantification the impacts of climate change and crop management on phenology of maize-based cropping system in Punjab, Pakistan. Agric For Meteorol 247:42-55

AgMIP (2013a) Guide for running AgMIP climate scenario generation tools with R in Windows. AgMIP http://www.agmip.org/ wp-content/uploads/2013/10/Guide-forRunning-AgMIP-Clima te-Scenario-Generation-with-R-v2.3.pdf

AgMIP (2013b) The coordinated climate-crop modeling project C3MP: an initiative of the agricultural model inter comparison and improvement project. C3MP Protocols and Procedures. AgMIP http://research.agmip.org/download/attachments/19988 99/ C3MP+Protocols+v2.pdf.

AgMIP (2014) Guide for regional integrated assessments: handbook of methods and procedures, version 5.1. AgMIP. http:// www. agmip. org/ wpcontent / uploads / 2013 / 06 / AgMIP Regional $\% 20$ Research-Team-Handbook-v4.2. pdf.

Ahmad A, Ashfaq M, Rasul G, et al (2015) Impact of climate change on the rice-wheat cropping system of Pakistan. In: Rosenzweig, C. and D. Hillel, (Eds.), Handbook of climate change and agroecosystems: the agricultural model intercomparison and improvement project (AgMIP). ICP Series on Climate Change Impacts, Adaptation, and Mitigation. Imperial College Press, London. pp. 219-258.

Ahmad B, Rasul G et al (2018) Statistically downscaled projections of CORDEX South Asia using quantile mapping approach over Pakistan region. Int J Glob Warm 16:435-460

Ahmad I, Wajid SA et al (2019) Optimizing irrigation and nitrogen requirements for maize through empirical modeling in semiarid environment. Environ Sci Pollut Res 26:1227-1237

Ahmed I, Saeed U et al (2018) Yield forecasting of spring maize using remote sensing and crop modeling in Faisalabad-Punjab Pakistan. J Indian Soc Remote Sens 46:1701-1711

Ahmed I, Ullah A. et al (2018a) Climate change impacts and adaptation strategies for agronomic crops, in: Climate change and agriculture. In Tech Open 1-15.

Ahmed I, Rahman MH, Ahmed S et al (2018b) Assessing the impact of climate variability on maize using simulation modeling under semi-arid environment of Punjab, Pakistan. Environ Sci Pollut Res 25:28413-28430. https://doi.org/10.1007/ s11356-018-2884-3

Amin A, Nasim W, Mubeen M, Ahmad A et al (2018) Simulated CSM-CROPGRO-cotton yield under projected future climate by SimCLIM for southern Punjab, Pakistan. Agric Syst 167:213-222

Araya A, Hoogenboom G et al (2015) Assessment of maize growth and yield using crop models under present and future climate in Southwestern Ethiopia. Agric For Meteorol 214:252-265

Araya A, Girma A, Getachew F (2015) Exploring impacts of climate change on maize yield in two contrasting agro-ecologies of Ethiopia. Asian J Appl Sci Engin 4:27-37

Asseng S, Ewert F (2013) Uncertainty in simulating wheat yields under climate change. Nat Clim Change 3:827-832

Asseng S, Ewert F et al (2014) Rising temperatures reduce global wheat production. Nat Clim Change 5:143-147

Aurbacher J, Parker PS et al (2013) Influence of climate change on short term management of field crops-a modeling approach. Agric Syst 119:44-57
Babel MS, Deb P, Soni P (2019) Performance evaluation of AquaCrop and DSSAT-CERES for maize under different irrigation and manure application rates in the Himalayan Region of India. Agric Res 8:207-217

Ban HY, Sim D, Lee KJ, Kim J (2015) Evaluating maize growth models "CERES-Maize" and "IXIM-Maize" under elevated temperature conditions. J Crop Sci Biotech 18:265-272

Bassu S, Brisson N et al (2014) How do various maize crop models vary in their responses to climate change factors? Glob Change Biol 20:2301-2320

Ceglar A, Pogacar T, Kajfez-Bogataj L, Crepin Z (2011) The simulation of phenological development in dynamic crop model: the Bayesian comparison of different methods. Agric For Meteorol 151:101-115

Challinor AJ, Smith MS, Thornton P (2013) Use of agro-climate ensembles for quantifying uncertainty and informing adaptation. Agric For Meteorol 170:2-7

Chattha W, Ahmad H, Farooq M, Shafqat W, Yaseen M, Ihsan M, Alzamanan S (2021) A novel parent selection strategy for the development of drought-tolerant cotton cultivars. Plant Genet Resour Charact Utilization 1-9https://doi.org/10.1017/S1479 262121000332

Chen C, Baethgen WE, Robertson A (2012) Contributions of individual variation in temperature, solar radiation and precipitation to crop yield in the North China Plain, 1961-2003. Clim Change 9:11-29

Chenu K, Chapman SC et al (2009) Simulating the yield impacts of organ-level quantitative trait loci associated with drought response in maize: gene-to-phenotype modeling approach. Genetics 183:1507-1523

Deb P, Shresth S, Babel MS (2014) Forecasting climate change impacts and evaluation of adaptation options for maize cropping in the hilly terrain of Himalayas: Sikkim, India. Theor Appl Climatol 121:649-667

Dimes JP, Keating BA et al (2003) An overview of APSIM, a model designed for farming systems simulation. Eur J Agron 18:267-288

Ewert F, Rötter RP et al (2015) Crop modelling for integrated assessment of risk to food production from climate change. Environ Model Softw 72:287-303

Gaydon DS, Balwinder-Singh E et al (2017) Evaluation of the APSIM model in cropping systems of Asia. Field Crops Res 204:52-75

Ghannoum O, Caemmerer SVON, Ziska LH, Conroy JP (2000) The growth response of $\mathrm{C}_{4}$ plants to rising atmospheric $\mathrm{CO}_{2}$ partial pressure: a reassessment. Plant Cell Environ 23:931-942

Hammad HK, Ahmad A, Farhad V, Abbas F (2013) Nitrogen stimulates phenological traits, growth and growing degree days of maize. Pak J Agric Sci 50:337-343

Hatfield JL, Prueger JH (2015) Temperature extremes: effect on plant growth and development. Weather Clim Extremes 10:4-10

He J, Dukes M, Jones J, Graham W, Judge V (2009) Applying GLUE for estimating CERES-Maize genetic and soil parameters for sweet corn production. T A S A B E 5:1907-1921

He J, Jones JW, Graham WD, Dukes MD (2010) Influence of likelihood function choice for estimating crop model parameters using the generalized likelihood uncertainty estimation method. Agric Syst 103:256-264

Holzworth DP, Huth NI et al (2014) APSIM-evolution towards a new generation of agricultural systems simulation. Environ Model Softw 62:327-350

Hoogenboom G (2000) Contribution of agrometeorology to the simulation of crop production and its applications. Agric For Meteorol 103:137-157

Hoogenboom G, Jones JW et al (2011) Decision support system for agro-technology system transfer, version 4.5 (CD-ROM). University of Hawaii, Honolulu 
Hoogenboom G, Jones JW et al (2015) Decision support system for agrotechnology transfer (DSSAT). Version 4.6. DSSAT Foundation, Prosser, WA

Hoogenboom G, Porter CH et al (2019) Decision support system for agrotechnology transfer (DSSAT) version 4.7.5.0 (www.DSSAT. net). DSSAT Foundation, Gainesville, Florida, USA.

Hunt LA, Boote KJ (1998) Data for model operation, calibration, and evaluation. In:Impact of climate change on the rice-wheat cropping system of Pakistan. In: Rosenzweig, C., Hillel, D. (Eds.), Handbook of climate change and agroecosystems: the agricultural model inter-comparison and improvement project (AgMIP). ICP Series on Climate Change Impacts, Adaptation, and Mitigation. Imperial College Press London. 219-258

IPCC (2007). Climate change: impacts, adaptation and vulnerability. Contribution of working group II to the fourth assessment report of the intergovernmental panel on climate change. Cambridge Uni Press Cambridge UK.

IPCC (2014) Climate change: impacts, adaptation, and vulnerability. Contribution of working group II to the fifth assessment report of the intergovernmental panel on climate change [Field CB, Barros VR, Dokken DJ, et al (ed.)]. Cambridge University Press, Cambridge United Kingdom and New York NY USA

IPCC (2021) Summary for policymakers. In: Climate change 2021: the physical science basis. Contribution of Working Group I to the Sixth Assessment Report of the Intergovernmental Panel on Climate Change [Masson-Delmotte V, Zhai P, Pirani A, Connors $S$ L et al (2021) (eds.)]. Cambridge University Press.

Iqbal W, Zahid M (2014) Historical and future trends of summer mean air temperature over South Asia. Pak J Meteorol 10:55-66

Ishfaq A, Ahmad B, Boote K, Hoogenboom G (2020) Adaptation strategies for maize production under climate change for semiarid Environments. Eur J Agron 115:126-40

Islam S, Cenacchi N, Sulser TB et al (2016) Structural approaches to modeling the impact of climate change and adaptation technologies on crop yields and food security. Glob Food Sec 10:63-70

Jones JW, Hoogenboom G et al (2003) The DSSAT cropping system model. Eur J Agron 18:235-265

Kang Y, Khan S, Ma X (2009) Climate change impacts on crop yield, crop water productivity and food security-A review. Progress Nat Sci 19:1665-1674

Kassie BT, Van Ittersum MK et al (2014) Climate induced yield variability and yield gaps of maize (Zea mays L.) in the central rift valley of Ethiopia. Field Crop Res 160:41-53

Keating BA, Carberry PS, Hammer GL et al (2003) An overview of APSIM a model designed for farming systems simulation. Eur J Agron 18:267-288

Khaliq T, Ahmad A, Hussain A, Ranjha M, Ali MA (2008) Impact of nitrogen rates on growth, yield and radiation use efficiency of maize under varying environments. Pak J Agri Sci 45:1-7

Knorzer H, Lawes R et al (2011) Evaluation and performance of the APSIM crop growth model for German winter wheat, maize and fieldpea varieties in mono cropping and intercropping systems. J Agric Sci Technol B 1:698-717

Lizaso JI, Boote KJ et al (2011) CSM-IXIM: a new maize simulation model for DSSAT Version 4.5. Agron J 103:766-779

Lizaso JI, Ruiz-Ramos M et al (2018) Impact of high temperatures in maize: phenology and yield components. Field Crops Res 216:129-140

Lizaso JI, Boote KJ, Jones JW, Porter V, Echarte L, Westgate ME, Sonohat G (2011) CSM-IXIM: a new maize simulation model for DSSAT version 4.5. Agron J 103:766-779

Lizaso JI, Batchelor WD, Westgate ME, Echarte L (2013) Enhancing the ability of CERES-Maize to compute light capture. Agric Syst 76:293-311

Lobell DB, Burke MB et al (2008) Prioritizing climate change adaptation needs for food security in 2030. Science 319:607-610
Lobell DB, Bänziger M, Magorokosho C, Vivek (2011) Nonlinear heat effects on African maize as evidenced by historical yield trials. Nat Clim Chang 1:42-45

Lv Z, Li F, Lu G (2019) Adjusting sowing date and cultivar shift improve maize adaption to climate change in China. Mitig Adapt Strateg Glob Chang 1:87-106

Mangani R, Tesfamariam EH et al (2019) Potential impacts of extreme weather events in main maize (Zea mays L.) producing areas of South Africa under rainfed conditions. Reg Environ Change 19:1441-1452

Martre P, Wallach D, Asseng S, Ewert F et al (2015) Multimodel ensembles of wheat growth: many models are better than one. Glob Change Biol 21:911-925

Mavromatis T, Boote KJ et al (2001) Developing genetic coefficients for crop simulation models with data from crop performance trials. Crop Sci 41:40-51

Mina U, Kumar R, Gogoi R, Bhatia A et al (2019) Effect of elevated temperature and carbon dioxide on maize genotypes health index. Ecol Indic 105:292-302

Mubeen M, Ahmad A et al (2016) Application of CSM-CERES Maize model in optimizing irrigated conditions. Outlook Agric 45:173-184

Mubeen M, Ahmad A, Hammad HM et al (2020) Evaluating the climate change impacts on water requirements of cotton-wheat in semi-arid conditions using DSSAT model. J Water Clim Change 11(4):1661-1675

Müller C, Elliott J (2015) The Global Gridded Crop Model intercomparison: approaches, insights and caveats for modelling climate change impacts on agriculture at the global scale. In: A. Elbehri, ed. Climate change and food systems: global assessments and implications for food security and trade. Rome, FAO.

Osborne T, Rose G, Wheeler T (2013) Variation in the global-scale impacts of climate change on crop productivity due to climate model uncertainty and adaptation. Agric For Meteorol 170:183-194

Pandey V, Patel HR, Karande BI (2007) Impact analysis of climate change on different crops in Gujarat, India. Imp Clim Change Agric 56:213-220

Porter JR (2005) Rising temperatures are likely to reduce crop yields. Nature 436:174

Rahman MH, Ahmad A et al (2018) Multi-model projections of future climate and climate change impacts uncertainty assessment for cotton production in Pakistan. Agric For Meteorol 253:94-113

Rahman MH, Ahmad A, et al (2019) Application of CSMCROPGROCotton model for cultivars and optimum planting dates: evaluation in changing semi-arid climate. Field Crop Reshttps://doi. org/10.1016/j.fcr.2017.007

Rasul G, Ahmad B (2012) Climate change in Pakistan. Focus Sindh Province. Pak Meteorol Dep Rep 8:89-107

Ritchie JT, Alagarswamy G (2003) Model concepts to express genetic differences in maize yield components. Agron J 95:4-9

Rosegrant MW, Tokgoz S, Bhandary P (2012) The new normal? A tighter global agricultural supply and demand relation and its implications for food security. Am J Agric Econ 95:303-309

Rosenzweig C, Jones JW, Hatfield JL (2013) Agricultural model intercomparison and improvement project (AgMIP): protocols and pilot studies. Agric For Meteorol 170:166-182

Rosenzweig C, Elliott J, Deryng D et al (2014) Assessing agricultural risks of climate change in the 21st century in a global gridded crop model intercomparison. Proc Natl Acad Sci 111:3268-3273

Ruane AC, Cecil LD et al (2013) Climate change impact uncertainties for maize in Panama: farm information, climate projections, and yield sensitivities. Agric For Meteorol 170:132-145

Ruane A C, Goldberg R, Chryssanthacopoulos J (2014) Climate forcing datasets for agriculturalmodeling: Merged products for 
gap-filling and historical climate series estimation. Agric Forest Meteorol 198-200

Ruane AC, Winter JM, McDermid SP, Hudson NI (2015) AgMIP climate datasets and scenarios for integrated assessment. in handbook of climate change and agroecosystems: the agricultural model inter comparison and improvement project (AgMIP) integrated crop and economic assessments, part 1. In: In: Rosenzweig, C, Hillel D (Eds.), ICP series on climate change impacts, adaptation, and mitigation, vol. 3. Imperial College Press. pp 45-78. https://doi.org/10.1142/9781783265640_0003

Ruane AC, McDermid SP et al (2017) Selection of a representative subset of global climate models that captures the profile of regional changes for integrated climate impacts assessment. Earth Perspect 4:1

Saddique Q, Cai H, Ishaque W, Chen H, Chau HW, Chattha MU, Hassan MU, Khan MI, He J (2019) Optimizing the sowing date and irrigation strategy to improve maize yield by using CERES (crop estimation through resource and environment synthesis)-maize model. Agronomy. 9(2):109. https://doi.org/10.3390/agronomy9020109

Saddique Q, Cai H, Xu J et al (2020a) Analyzing adaptation strategies for maize production under future climate change in Guanzhong Plain, China. Mitig Adapt Strateg Glob Change 25:1523-1543. https://doi.org/10.1007/s11027-020-09935-0

Saddique Q, Khan MI, Habib ur Rahman M, Jiatun X, Waseem M, Gaiser T, Mohsin Waqas M, Ahmad I, Chong L, Cai H (2020b) Effects of elevated air temperature and $\mathrm{CO} 2$ on maize production and water use efficiency under future climate change scenarios in Shaanxi Province China. Atmosphere 11(8):843. https://doi.org/ 10.3390/atmos11080843

Saddique Q, Liu De Li, Wang Bin, Feng Puyu, He Jianqiang, Ajaz Ali, Ji Jianmei, Jiatun Xu, Zhang Chao, Cai Huanjie (2020c) Modelling future climate change impacts on winter wheat yield and water use: a case study in Guanzhong Plain, northwestern China. Eur J Agron 119:2020. https://doi.org/10.1016/j.eja.2020.126113

Shafqat W, Jaskani MJ, Maqbool R, Khan AS, Ali Z (2019) Evaluation of citrus rootstocks against drought, heat and combined stress based on growth and photosynthetic pigments. Int J Agric Biol 22:1001-1009

Shafqat W, Jaskani MJ, Maqbool R, CHattha WS, Ali Z, Naqvi SM, Haider MS, Khan IA, Vincent CI (2021) Heat shock protein and aquaporin expression enhance water conserving behavior of citrus under water deficits and high temperature conditions. Environ Exp Bot 181https://doi.org/10.1016/j.envexpbot.2020.104270

Soler C, Hoogenboom G, Sentelhas PC, Duarte AP (2007) Impact of water stress on maize grown off-season in a subtropical environment. J Agro Crop Sci 193:247-261
Taylor KE, Stouffer RJ, Meehl GA (2012) An overview of CMIP5 and the experiment design. Bull Am Meteorol Soc 93:485-498

Tojo SCM, Sentelhas PC, Hoogenboom G (2007) Application of the CSM-CERES-Maize model for planting date evaluation and yield forecasting for maize grown off seasonin a subtropical environment. Eur J Agron 27:165-177

Trenberth KE (2011) Changes in precipitation with climate change. Clim Res 47:123-138

Ullah A, Ahmad I, Ahmad A, Khaliq T et al (2019) Assessing climate change impacts on pearl millet under arid and semi-arid environments using CSM-CERES-Millet model. Environ Sci Pollut Res 26:6745-6757

Uusitalo L, Lehikoinen A, Helle I, Myrberg K (2015) An overview of methods to evaluate uncertainty of deterministic models in decision support. Environ Model Softw 63:24-31

Wahid A, Gelani S, Ashraf M, Foolad M (2007) Heat tolerance in plants: an overview. Environ Exp Bot 61:199-223

Wajid F, Ahmad A, Khaliq T et al (2010) Quantification of growth, yield and radiation use efficiency of promising cotton cultivars at varying nitrogen levels. Pak J Bot 42(3):1703-1711

Wallach D, Goffinet B (1989) Mean squared error of prediction as a criterion for evaluating and comparing system models. Ecol Model 44:299-306

Wiebe K, Robinson S, Cattaneo A (2019) Climate change, agriculture and food security: impacts and the potential for adaptation and mitigation. Sustain Food Agric Elsevier 55-74.

Wilby RL, Charles SP et al (2004) Guidelines for use of climate scenarios developed from statistical downscaling methods. Analysis 27:1-27

Willmott CJ, Ackleson SG, Davis RE et al (1985) Statistics for the evaluation and comparison of models. J Geophys Res Oceans 90:8995-9005. https://doi.org/10.1029/JC090iC05p08995

Yakoub A, Lloveras J, Biau A et al (2017) Testing and improving the maize models in DSSAT: development, growth, yield, and N uptake. Field Crops Res 212:95-106

Yasin M, Ahmad A et al (2019) Evaluating the impact of thermal variations due to different sowing dates on yield and quality of spring maize. Int J Agric Biol 21:922-928

Zhang W, Ricketts TH, Kremen C et al (2007) Ecosystem services and dis-services to agriculture. Ecol Econ 64:253-260

Publisher's note Springer Nature remains neutral with regard to jurisdictional claims in published maps and institutional affiliations. 